\title{
SURVEI PEMANFAATAN PETA DALAM PEMBELAJARAN IPS BAGI GURU-GURU SD DI KOTA DEPOK
}

\author{
Suhardjo $^{1}$, Aris Munandar ${ }^{2}$ \\ Program Studi Geografi Fakultas Ilmu Sosial Universitas Negeri Jakarta \\ Email: ${ }^{1}$ mr_suhardjo@yahoo.com, ${ }^{2}$ amunandar@unj.ac.id
}

\begin{abstract}
The purpose of this study was to reveal and find out how much use maps as social studies learning media for elementary school teachers. The study was carried out in several elementary schools in the Depok City area in July - August 2021. The method used in this study was a descriptive method with a survey approach through sampling techniques using random sampling of elementary school teachers with a sample of 35 people. people. The results showed that from map-based social studies learning activities, starting from making maps, reading maps, analyzing maps and interpreting and utilizing maps, most of the teachers had carried out their duties. The results showed that: 1) learning by using map media, the teacher has created a learning environment and strategies that evoke student involvement physically, mentally and emotionally, 2) social studies learning in elementary schools using map media, student participation increases, 3 ) the effective use of map media can increase meaning in the social studies learning process in elementary schools.
\end{abstract}

Keywords: maps; use and utilization of maps; social studies learning.

Abstrak

Tujuan Penelitian ini adalah untuk mengungkap dan mengetahui seberapa besar pemanfaatan peta sebagai media pembelajaran IPS bagi Guru-guru SD. Penelitian dilaksanakan di beberapa Sekolah Dasar di wilayah Kota Depok pada bulan Juli - Agustus 2021. Metode yang digunakan dalam penelitian ini adalah metode deskriptif dengan pendekatan survei melalui teknik sampling adalah random sampling terhadap guru-guru Sekolah Dasar sejumlah sampel 35 orang. Hasil penelitian menunjukkan bahwa dari kegiatan pembelajaran IPS berbasis peta dari membuat peta, membaca peta, menganalisis peta maupun menginterpretasi dan pemanfaatan peta dengan sebagian besar guru telah melaksanakan tugasnya. Hal ini dapat dilihat bahwa : 1) pembelajaran dengan menggunakan media peta, guru telah menciptakan lingkungan belajar dan strategi yang membangkitkan keterlibatan siswa secara fisik, mental dan emosional, 2) pembelajaran Ilmu Pengetahuan Sosial di Sekolah Dasar dengan menggunakan media peta, peran serta siswa menjadi lebih meningkat, 3) penggunaan media peta secara efektif dapat meningkatkan kebermaknaan dalam proses pembelajaran IPS di Sekolah Dasar.

Kata Kunci: peta; penggunaan dan pemanfaatan peta; pembelajaran IPS.

\section{PENDAhUluan}

Salah satu ciri Kurikulum 2013, khususnya untuk SD adalah bersifat tematik integratif. Dalam pendekatan ini, mata pelajaran IPA dan IPS sebagai materi pembahasan pada semua mata pelajaran. Prosesnya, tema-tema yang ada pada dua pelajaran itu diintegrasikan ke dalam sejumlah mata pelajaran. Untuk IPA menjadi materi pembahasan pelajaran Bahasa Indonesia, Matematika, dan lain-lain. Sedangkan untuk IPS menjadi materi pembahasan pelajaran PPKN, Bahasa Indonesia, dan lain-lain.

Dalam Kurikulum 2013 memuat berupa Kompetensi Inti dan Kompetensi 
Dasar. Kompetensi Inti harus menggambarkan kualitas yang seimbang antara pencapaian hard skills dan soft skills. Kompetensi inti dirancang dalam empat kelompok yang saling terkait yaitu berkenaan dengan sikap keagamaan (Kompetensi Inti 1), Sikap Sosial (Kompetensi Inti 2), Pengetahuan (Kompetensi Inti 3), dan penerapan pengetahuan (Kompetensi Inti 4). Keempat kelompok itu menjadi acuan dari Kompetensi Dasar dan harus dikembangkan dalam setiap peristiwa pembelajaran secara integratif.

Berbeda dengan kurikulum sebelumnya, kurikulum tahun 2006 lebih simpel dan efektif, namun memiliki nuansa yang padat dan memiliki paradigma baru dalam pembelajaran IPS. Hal ini diharapkan agar guru dapat mandiri, mau dan mampu menentukan sendiri pendekatan, metode dan alat evaluasi yang disesuaikan dengan kebutuhan dan kondisi yang dihadapi.

Materi pelajaran Ilmu Pengetahuan Sosial di Sekolah Dasar (SD) terdiri dari materi Geografi, Sejarah, Sosiologi, dan Ekonomi. Materi IPS SD tidak tampak secara nyata, namun tertata secara terpadu dalam standar kompetensi yang dimulai sejak kelas satu sampai dengan kelas enam. Pembelajaran IPS pada kelas satu sampai kelas tiga dilaksanakan melalui pendekatan tematik, sedangkan pada kelas empat sampai kelas enam dilaksanakan melalui pendekatan pelajaran. Kurikulum SD tahun 2006 memberi peluang kepada pengembang kurikulum (Guru) untuk melaksanakan paradigma baru pembelajaran di SD yang mengacu pada pendekatan PAKEM (Pembelajaran Aktif, Kreatif, Efektif, dan Menyenangkan).

Geografi merupakan ilmu pengetahuan yang mencitrakan (to describe), menerangkan sifat-sifat bumi, menganalisa gejala-gejala alam dan penduduk serta mempelajari corak khas mengenai kehidupan dan berusaha mencari kehidupan dan berusaha mencari fungsi dari unsur-unsur bumi dalam ruang dan waktu (Bintarto, 1988). Dalam seminar dan lokakarya Ikatan Geograf Indonesia (IGI) di kota Semarang tahun 1982 dimunculkan definisi geografi yaitu ilmu yang mempelajari persamaan dan perbedaan gejala geosfer dalam sudut pandang keruangan dan dalam konteks kewilayahan. Dari kedua definisi tersebut didapatkan penjelasan penting tentang geografi yaitu pencitraan (description), penjelasan (explanation), 
penganalisaan (analyzing), dan penerapan (application).

Kenyataan di lapangan banyak ditemukan seorang guru IPS di SD dalam pembelajaran dengan materi geografi lebih banyak menggunakan metode ceramah. Kesemua metode pengajaran tersebut, penggunaan peta sangat diperlukan, karena informasi yang disajikan dalam peta dapat dengan mudah diketahui, dianalisa, dan diinterpretasi.

Hasil penelitian yang dilakukan oleh Dirgayusa, Dantes, Natajaya (2015) menunjukan, pertama, terdapat perbedaan antara motivasi belajar sebelum menggunakan media peta taktual dalam pembelajaran dibandingkan dengan motivasi belajar setelah menggunakan media peta taktual dalam pembelajaran. Kedua, terdapat perbedaan antara prestasi belajar sebelum menggunakan media peta taktual dalam pembelajaran dibandingkan dengan prestasi belajar setelah menggunakan media peta taktual dalam pembelajaran. Hal ini membuktikan bahwa media peta taktual berpengaruh terhadap motivasi dan prestasi belajar.

Penelitian lain juga membuktikan bahwa media peta bermanfaat untuk siswa dalam pembelajaran IPS seperti yang dikemukakan oleh Huda \& Suprayitno (2014) menjelaskan bahwa hasil belajar IPS siswa dapat meningkat melalui Penelitian Tindakan Kelas dengan memanfaatkan media peta. Hasil penelitian ini juga didukung oleh penelitian dilakukan oleh Suseno, Sugiyono, Uliyanti (2014) yang mengemukakan bahwa media pembelajaran peta dapat meningkatkan hasil belajar siswa pada pembelajaran IPS sehingga guru IPS perlu diberikan bekal pengetahuan tentang pembuatan media peta untuk pembelajaran IPS.

Media sebagai sumber pembelajaran erat kaitannya dengan peran guru. Guru tidak cukup memiliki pengetahuan tentang media tetapi dituntut untuk terampil memilih, menggunakan serta mengusahakan memilih media yang tepat, kalau memungkinkan guru memiliki kemampuan untuk merancang dan membuat media sendiri. Memilih dan menggunakan media, perlu memperhatikan aspek tujuan, materi, metode dan evaluasi. Pengguanaan media bukan semata-mata melaksanakan salah satu komponen pengajaran, tetapi dengan media benar-benar berguna untuk memudahkan penguasaan siswa 
dalam belajar. Upaya untuk mencapai tujuan pembelajaran Pendidikan IPS, sangat terkait dengan kemampuan guru dalam memanfaatkan media yang tersedia untuk kebutuhan siswanya, siswa dilatih menjadi terampil dan penuh pengalaman dalam menggunakan media. Proses pembelajaran yang didukung oleh media secara lengkap dapat menumbuhkan motivasi siswa dalam belajar. Berdasarkan rumusan masalah tersebut di atas maka masalahnya dapat dibatasi pada: "Bagaimanakah tingkat pemanfaatan peta dalam pembelajaran IPS SD oleh guru guru di kota Depok"?

\section{METODOLOGI PENELITIAN}

Metode yang digunakan dalam penelitian ini adalah survei. Dalam survei, informasi dikumpulkan dari responden (guru) menggunakan angket atau kuesioner secara daring menggunakan Google Form. Secara umum, penelitian survei dideskripsikan sebagai penelitian ilmiah yang datanya dikumpulkan dari sampel yang telah dipilih dari populasi guru jenjang pendidikan sekolah dasar di Kota Depok. Penelitian dilakukan pada bulan Juli sampai Agustus 2021.

\section{HASIL DAN PEMBAHASAN}

Berikut ini disajikan data hasil survey terhadap guru terkait dengan pemanfaatan peta.

\section{(1) Menjelaskan Cara Membuat Peta}

Dalam kegiatan pembelajaran ini, guru membagi dalam empat hal terkait dengan membuat peta, yaitu:

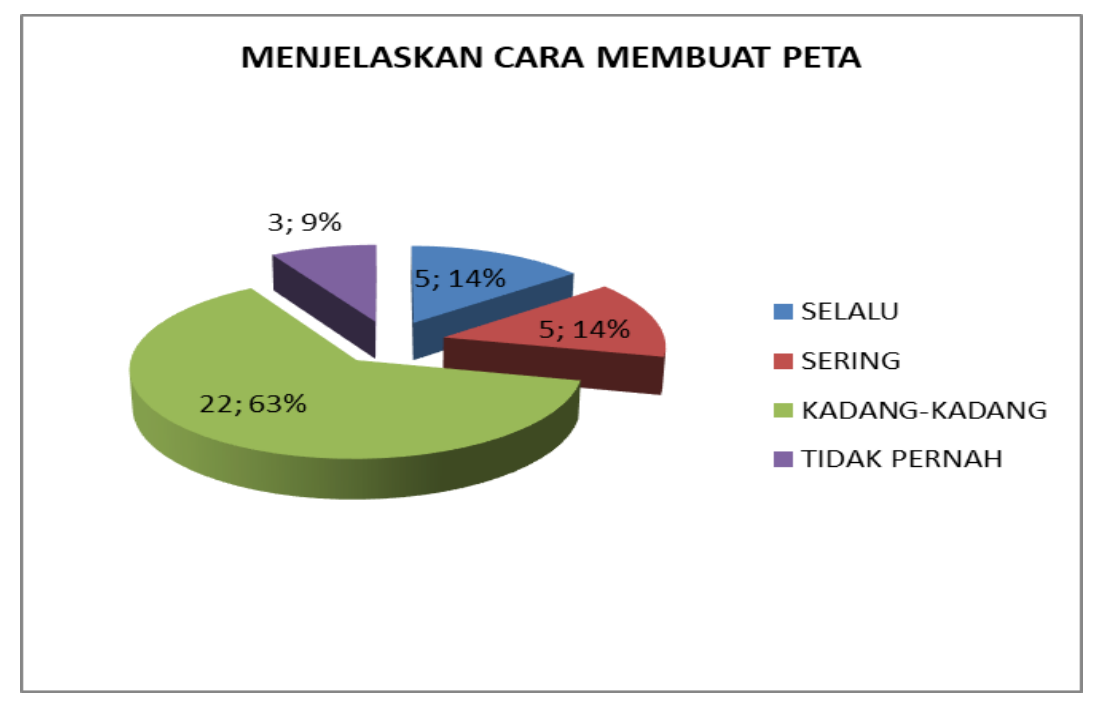

Gambar 1. Menjelaskan Cara Membuat Peta (Sumber: Hasil Penelitian, 2021) 


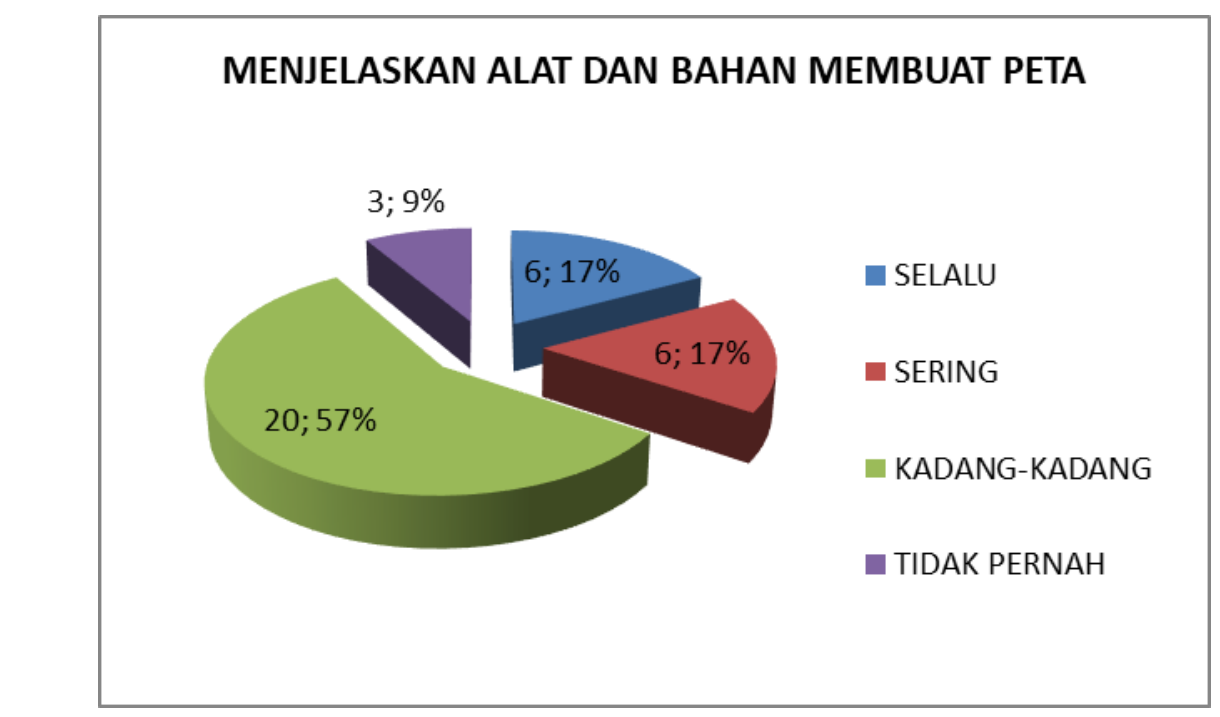

\section{Gambar 2. Menjelaskan Alat dan Bahan Membuat Peta (Sumber: Hasil Penelitian, 2021)}

Dari gambar 1 dapat dijelaskan sebanyak 5 orang guru $(14 \%)$ menjawab selalu, selanjutan sebanyak 5 orang guru (14\%) menyatakan sering, dan sebanyak 22 orang guru $(63 \%)$ kadang-kadang serta sejumlah 3 orang guru (9\%) menyatakan tidak pernah dalam kegiatan seorang guru ketika menjelskan cara membuat peta kepada peserta didiknya. Dengan demikian, sebagian besar guru telah mampu menjelaskan cara membuat peta dan hanya sebagian kecil saja yang belum pernah melaksanakan menjelaskan cara membuat peta tersebut.
(2) Menjelaskan Alat dan Bahan

\section{Membuat Peta}

Berdasarkan gambar 2 tersebut dapat diketahui bahwa sebagian besar guru $(91 \%)$ telah menyatakan dalam kegiatan pembelajarannya dalam pembuatan peta diawali oleh penjelasan tentang alat dan bahan yang harus dipersiapkan dalam proses pembuatan sebuah peta, dan sebagian kecil guru (9\%) tidak pernah melaksanakan kegiatan tersebut. 
Jurnal Parameter Volume 33 No. 1

DOI : doi.org/10.21009/parameter.331.03

P-ISSN : 0216-261X E-ISSN : 2620-9519

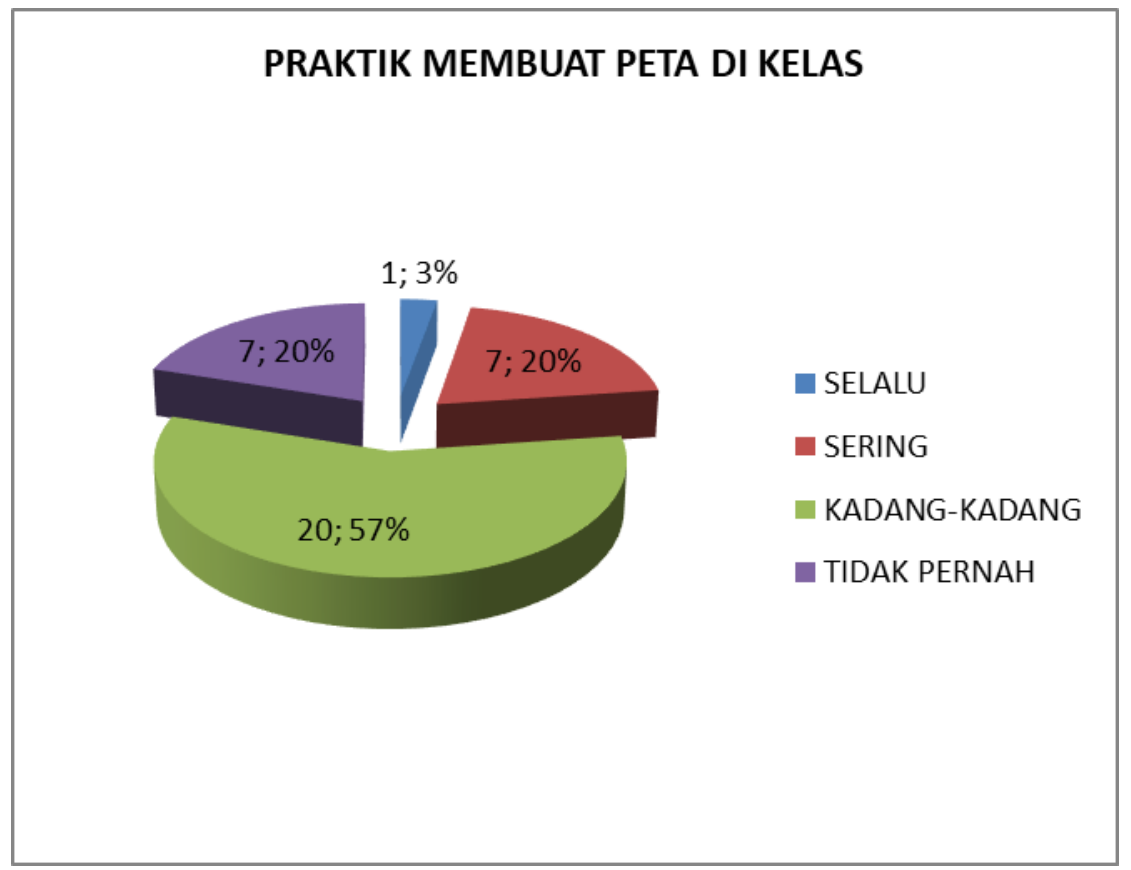

Gambar 3. Praktik Membuat Peta di Kelas (Sumber : Hasil Penelitian, 2021)

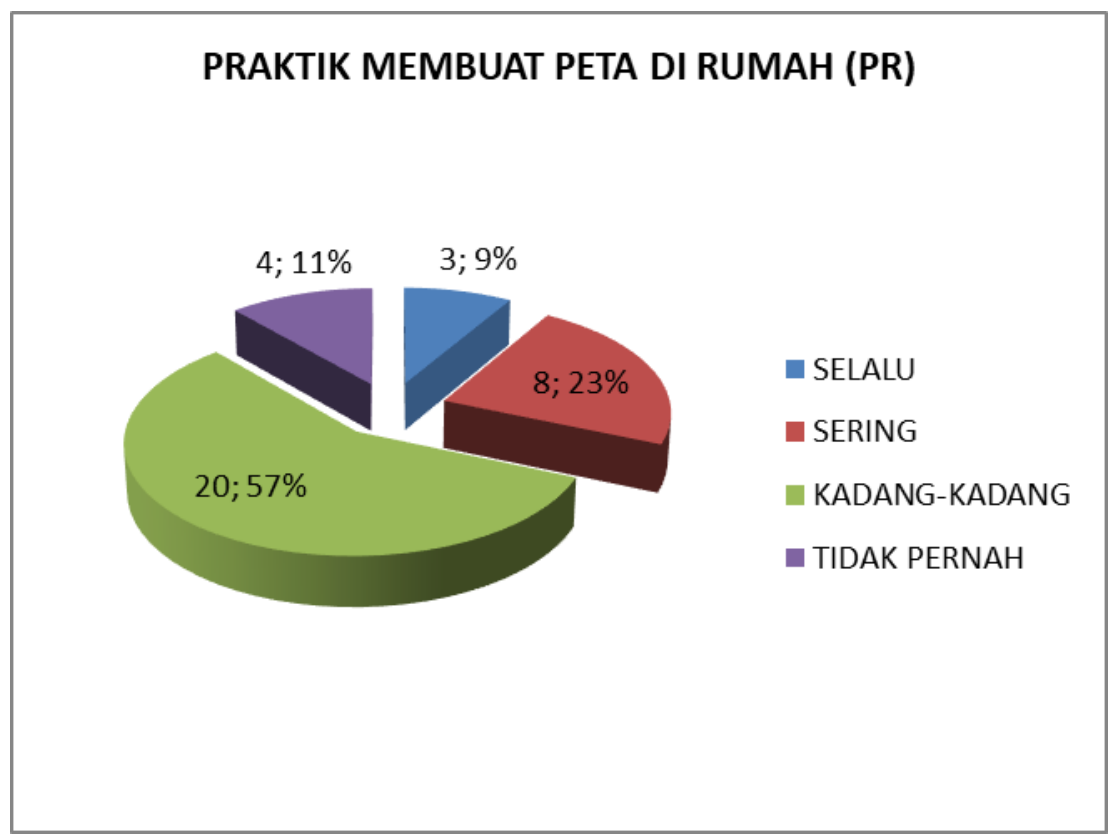

Gambar 4. Praktik Membuat Peta di Rumah (Sumber: Hasil Penelitian, 2021)

Aktivitas pembelajaran saat ini mampu memberikan tugas praktikum sesuai kurikulum diharapkan dapat kepada peserta didiknya untuk membuat menumbuhkan kreativitas peserta didik. peta pada saat pembelajaran berlangsung Oleh karenanya seorang guru harus dengan menyesuaikan waktu yang ada 
dan bisa dikerjakan baik secara individual maupun kelompok.

Berdasarkan gambar 3 tersebut dapat diketahui bahwa 97\% guru telah melaksanakan kegiatan pembelajaran melalui praktik langsung di kelas dan hanya $3 \%$ yang belum pernah melakukannya. Satu hal yang dapat meningkatkan daya keterampilan siswa dalam memahami pembuatan peta diantaranya melalui banyak praktikum baik itu di kelas maupun di rumah. Seorang guru dalam meningkatkan ketrampilan tersebut antara lain memberikan tugas melalui praktik membuat peta di rumah sebagai pekerjaan rumah. Dari data gambar 4 tersebut dapat diketahui sebagian besar guru $(89 \%)$ telah melakukan pemberian tugas kepada siswanya untuk membuat peta di rumah, dan sejumlah $11 \%$ belum pernah melakukannya.

Beberapa hal yang berkaitan dengan membaca peta antara lain adalah: Menyebutkan judul peta yang disampaikan oleh seorang guru dalam pembelajarannya tentang IPS merupakan awal penjelasan yang berhubungan dengan substansi materi pokok tentang peta sebagai media sesuai dengan pokok bahasan yang diterangkannya. Menyebutkan judul peta berarti menunjukkan bahwa wilayah yang bersangkutan terletak di mana dan tentang apa yang akan menjadi obyek dari peta tersebut.

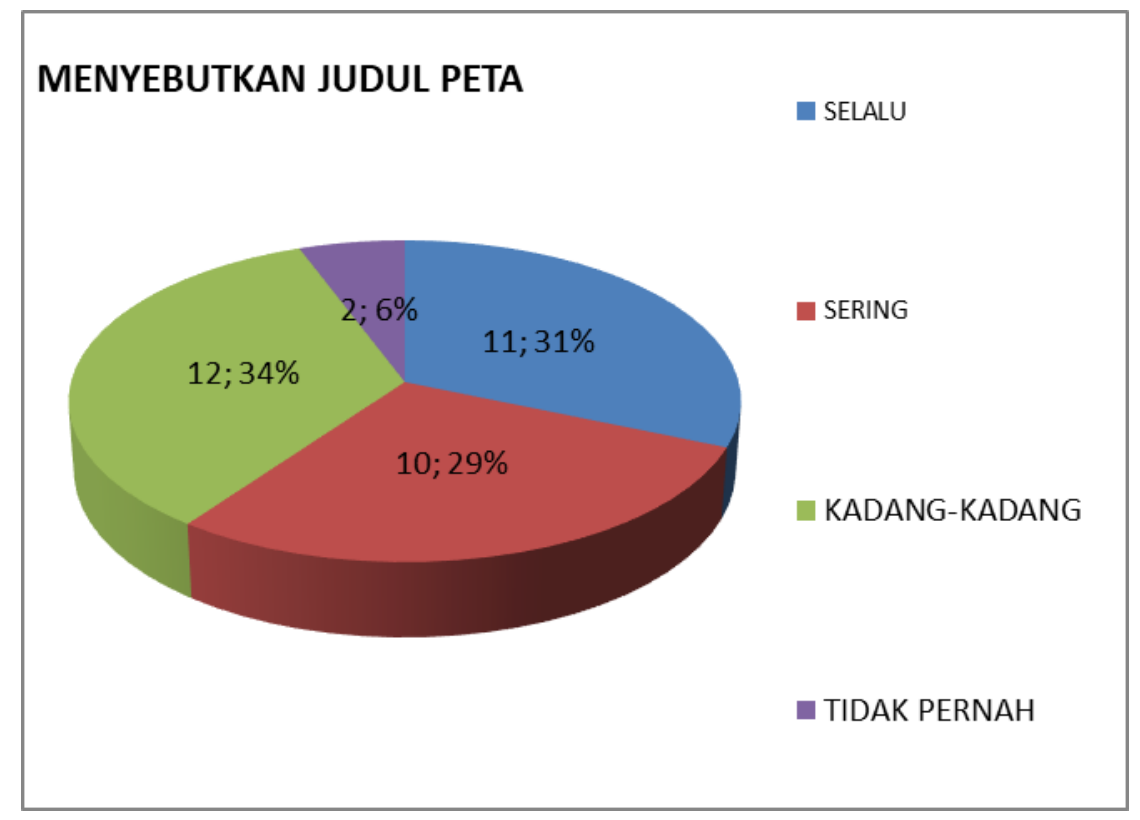

Gambar 5. Menyebutkan Judul Peta (Sumber: Hasil Penelitian, 2021) 


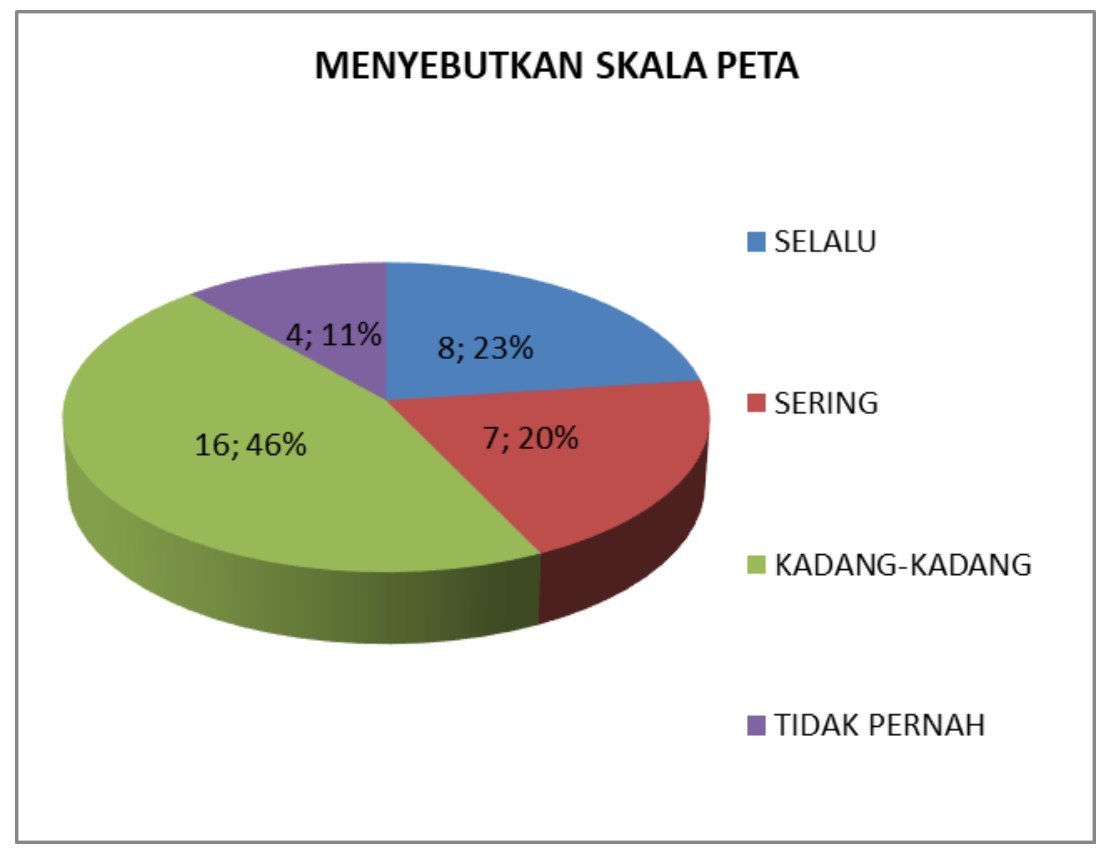

\section{Gambar 6. Menyebutkan Skala Peta (Sumber: Hasil Penelitian, 2021)}

Berdasarkan gambar 5 tersebut dapat dijelaskan bahwa dari 35 responden guru sebanyak 11 orang (31\%) memberikan respon selalu menyebutkan judul peta, sementara itu sebanyak 10 orang (29\%) merespon sering, dan menjawab kadang-kadang sebanyak 12 orang (34\%), sedangkan sebanyak 2 orang $(6 \%)$ merespon tidak pernah menyebutkan judul peta.

Data tersebut menjelaskan bahwa hampir semua guru merespon positif betapa pentingnya makna sebuah judul peta untuk disampaikan kepada para peserta sebagai awal penjelasan materi sesuai pokok bahasannya, dan jumlah yang sangat kecil menyatakan tidak pernah menyebutkan judul peta.
Skala peta merupakan satuan ukuran yang dapat menjelaskan hal-hal yang berkaitan dengan jarak antar satu titik ke titik lainnya maupun luas wilayah dari peta yang bersangkutan. Hasil survei menunjukkan bahwa sebagian besar guru 89\% menyatakan telah menyebutkan skala peta dalam pembelajaran yang terkait dengan materi peta dan sejumlah $11 \%$ belum pernah menyebutkan tentang skala peta dalam kaitannya dengan materi tentang peta.

Orientasi atau arah dalam peta menunjukkan suatu posisi letak dari suatu tempat yang secara simbolis ditetapkan sebagai Utara - Selatan Barat - Timur. Hal ini penting disampaikan agar peserta didik mampu 
memahami pada posisi dimana sesuatu tempat ini berada dibandingkan dengan tempat lainnya. Orientasi /arah itu ditulis dalam satuan derajat, menit, dan detik sebagai letak absolut maupun disebutkan dalam arah ke mana atau di mana lokasi wilayah/daerah tersebut dikaitkan dengan wilayah/daerah lain disekitarnya.

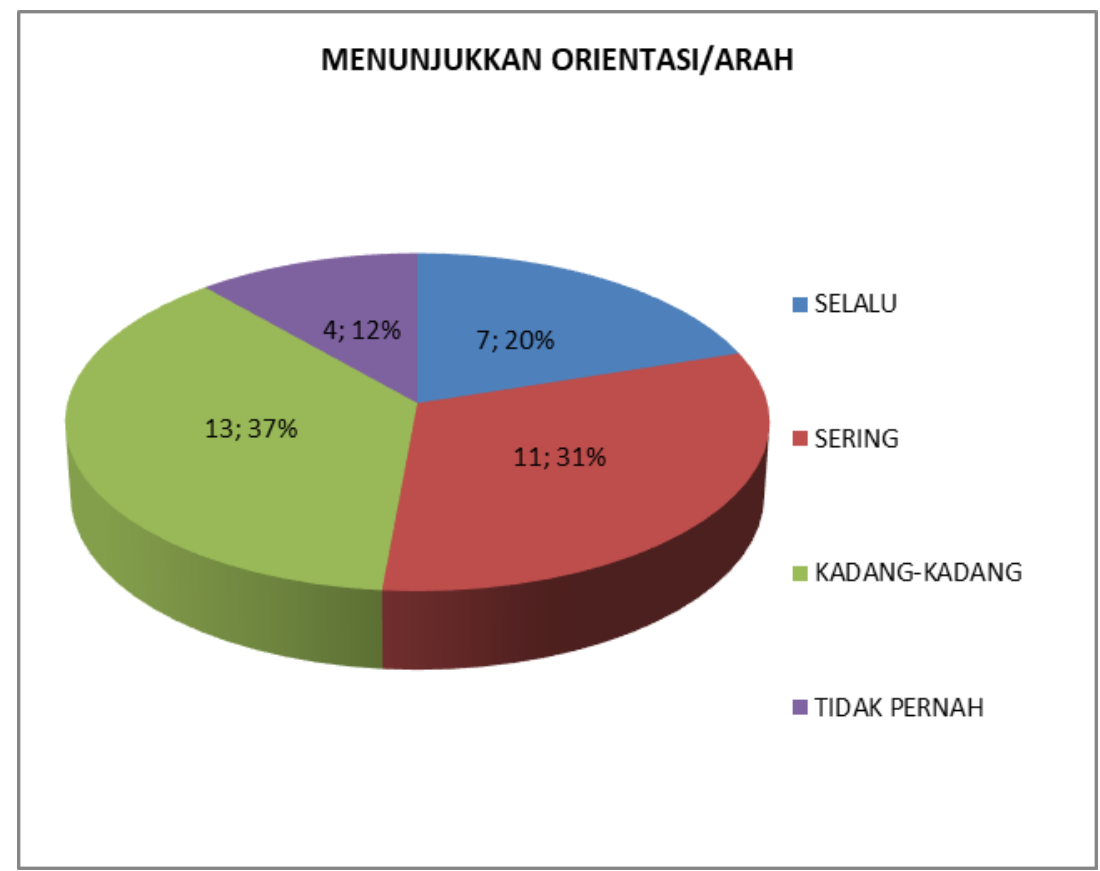

Gambar 7. Menunjukkan Orientasi/Arah (Sumber: Hasil Penelitian, 2021)

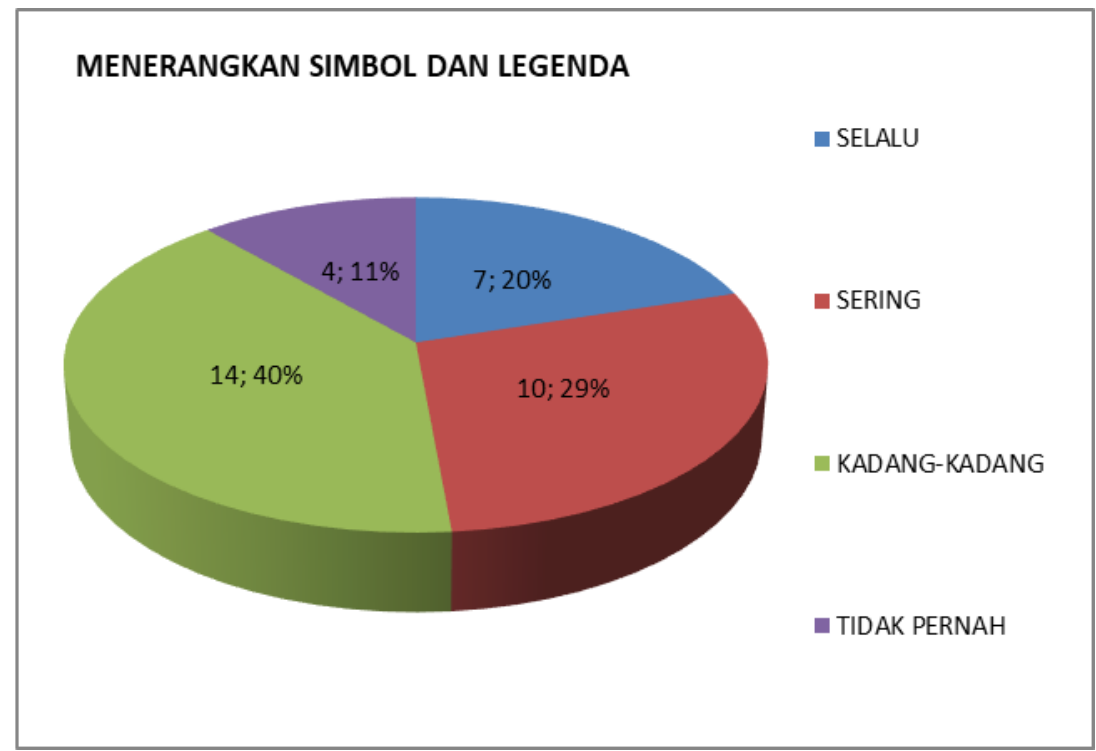

Gambar 8. Menerangkan Simbol dan Legenda (Sumber: Hasil Penelitian, 2021)

Hasil survei menyebutkan bahwa sebesar $88 \%$ guru telah melaksanakan kegiatan pembelajaran dengan peta dengan tidak lupa menunjukkan 
orientasi/arah dari peta yang disajikan sesuai dengan topik bahasan yang disajikan dan sebesar $12 \%$ guru belum pernah melakukan hal tersebut.

Hal yang paling penting dan pokok dalam kegiatan membaca peta adalah diantaranya guru harus mampu menjelaskan simbol-simbol yang ada dalam peta serta legenda yang memberi keterangan tentang simbol-simbol tersebut. Melalui penjelasan oleh guru terkait dengan simbol dan legenda pada sebuah peta tentunya akan dengan mudah peserta didik mampu memahami isi peta yang bersangkutan.

Hasil survei menunjukkan bahwa sebanyak 4 orang guru (11\%) tidak pernah menerangkan tentang simbol dan legenda. Berikutnya adalah sebanyak 31 orang guru (89\%) pernah menerangkan tentang simbol dan legenda dengan rincian 7 orang guru (20\%) selalu, 10 orang guru $(29 \%)$ sering, dan 14 orang guru (40\%) kadang-kadang.

Posisi muka bumi dalam peta ditentukan dengan berapa angka garis lintang (paralel) dan berapa angka garis bujur (meridian). Ini menunjukkan lokasi absolut dari sebuah titik baik berupa desa, kota, bahkan mungkin Indonesia berapa letak lintang dan bujurnya. Tujuannya adalah memudahkan untuk navigasi, jarak tempuh maupun berkaitan dengan posisi sesuatu wilayah atau daerah manakala terjadi bencana.

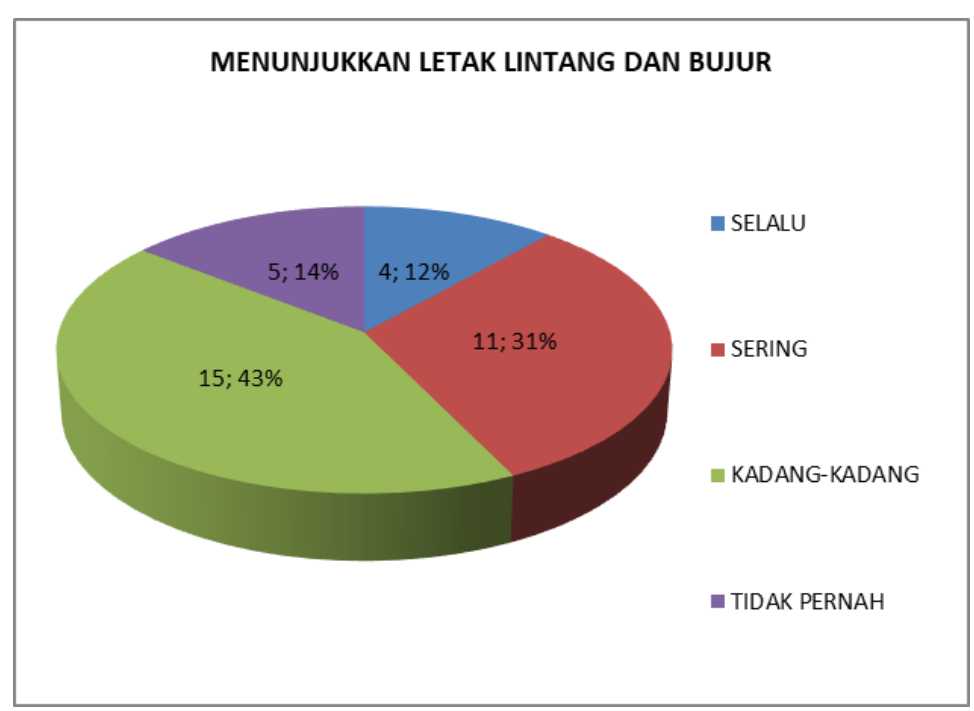

Gambar 9. Menunjukkan Letak Lintang dan Bujur (Sumber: Hasil Penelitian, 2021) 


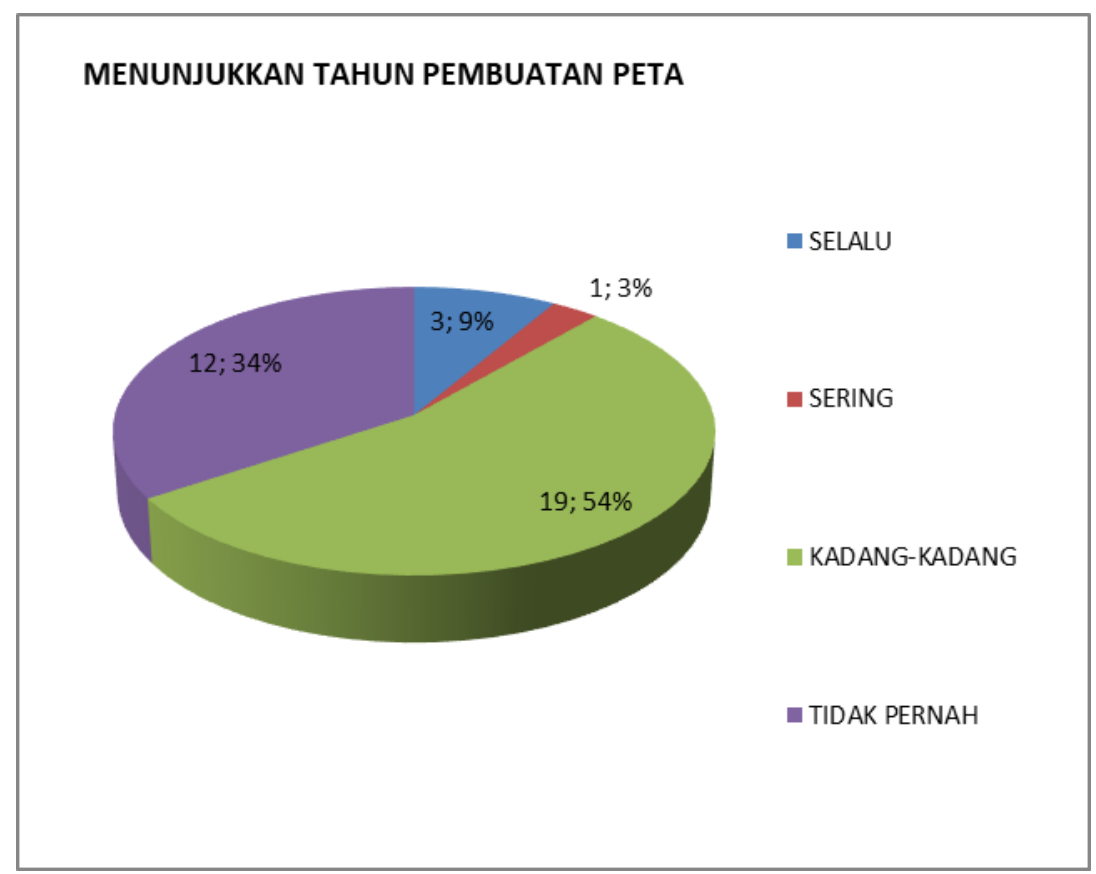

Gambar 10. Menunjukkan Tahun Pembuatan Peta (Sumber: Hasil Penelitian, 2021)

Hasil survei menunjukkan bahwa sebanyak 5 orang guru (14\%) tidak pernah menunjukkan letak lintang dan bujur. Berikutnya adalah sebanyak 30 orang guru $(86 \%)$ pernah menunjukkan letak lintang dan bujur dengan rincian 4 orang guru (12\%) selalu, 11 orang guru $(31 \%)$ sering, dan 15 orang guru (43\%) kadang-kadang.

Hasil survei menunjukkan bahwa sebanyak 12 orang guru (34\%) tidak pernah menunjukkan tahun pembuatan peta. Berikutnya adalah sebanyak 23 orang guru $(66 \%)$ pernah menunjukkan tahun pembuatan peta, dengan rincian 3 orang guru (9\%) selalu, 1 orang guru (3\%) sering, dan 19 orang guru (54\%) kadang-kadang.

Lokasi atau lokus merupakan tempat dimana obyek tersebut berada misalnya Peta Kepadatan Penduduk di DKI Jakarta tahun 2020. Ini berarti kepadatan penduduk tersebut menunjukkan terjadi di DKI Jakarta. 


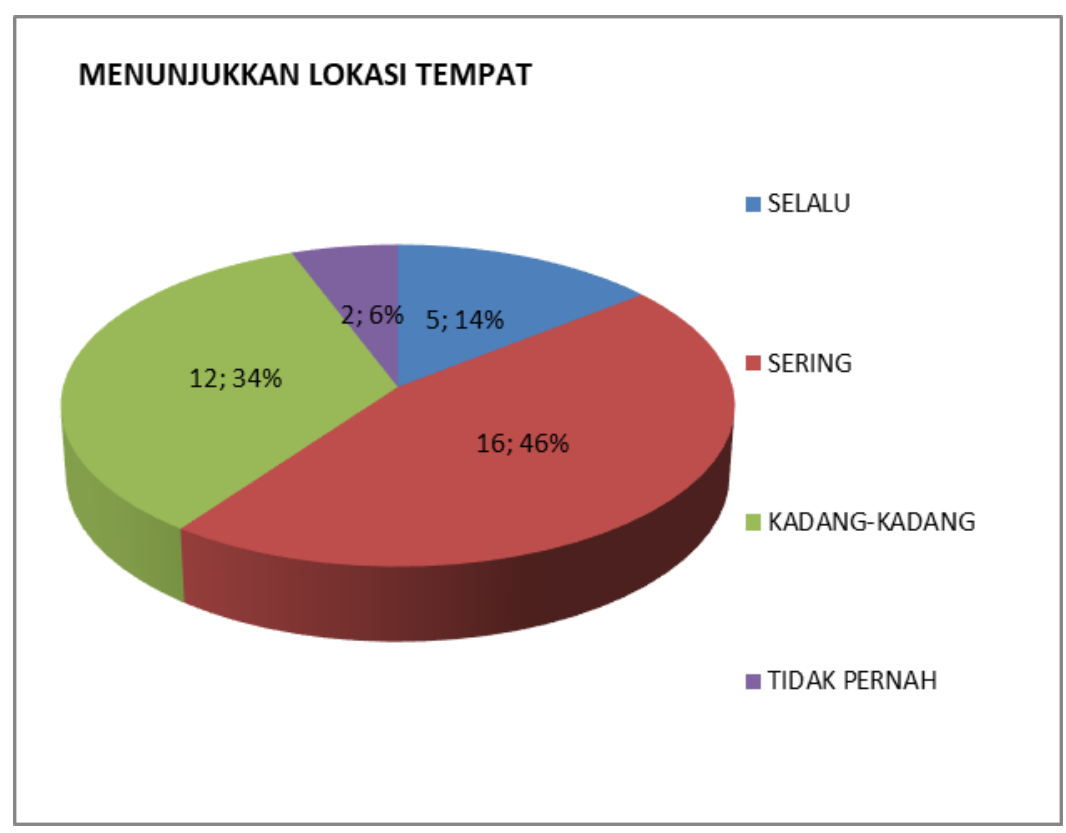

Gambar 11. Menunjukkan Lokasi Tempat (Sumber: Hasil Penelitian, 2021)

Hasil survei menunjukkan bahwa sebanyak 2 orang guru (6\%) tidak pernah menunjukkan tahun pembuatan peta. Berikutnya adalah sebanyak 32 orang guru $(94 \%)$ pernah menunjukkan lokasi tempat. dengan rincian 5 orang guru (14\%) selalu, 16 orang guru (46\%) sering, dan 12 orang guru (34\%) kadangkadang.

\section{Analisis Peta}

Bagian analisis peta merupakan hal yang penting manakala pembelajaran berbasis peta dalam mata pelajaran IPS membahas hubungan antara variabel yang satu dengan variabel lainnya sehingga pengalaman mengajar dan kualifikasi jenjang pendidikan yang ditunjukkan oleh tingkat pendidikan dan usia guru menjadi pertimbangan dasar untuk menjelaskan kepada peserta didik agar konten masalah dapat dipahami.

Beberapa hal yang dapat disurvei antara lain baagaimana seorang guru memberikan respon yang sebarkan melalui google form seperti berikut ini:

(1) Menghitung Kepadatan Penduduk

Kepadatan penduduk merupakan rasio antara jumlah penduduk dalam satuan luas wilayah ( $\mathrm{km}$ persegi). Dari materi ini, peserta didik dapat menganalisis berbagai sumber-sumber pembelajaran, alasan wilayah ini memiliki tingkat kepadatan penduduk yang tinggi atau rendah. 


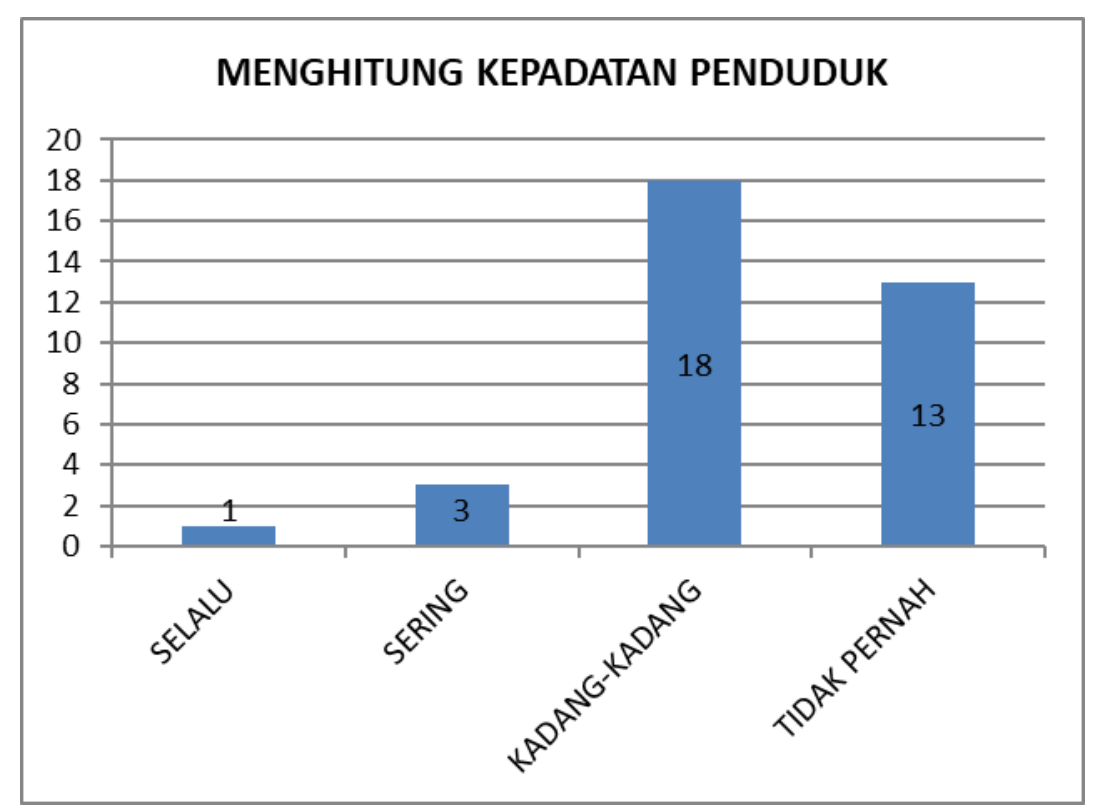

Gambar 12. Menghitung Kepadatan Penduduk (Hasil Penelitian, 2021)

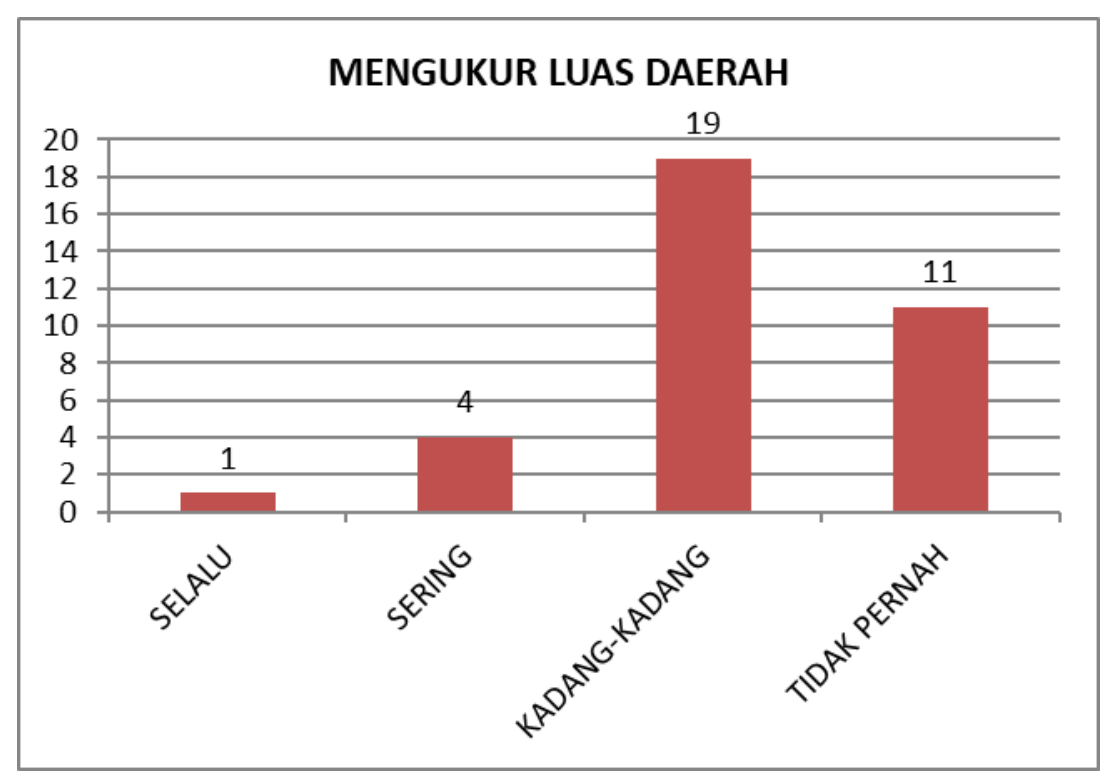

Gambar 13. Mengukur Luas Daerah/Wilayah (Hasil Penelitian, 2021)

Hasil survei menunjukkan bahwa sebanyak 13 orang guru (37\%) tidak pernah menghitung kepadatan penduduk pada setiap wilayah. Berikutnya adalah sebanyak 22 orang guru (63\%) pernah menunjukkan lokasi tempat. Dengan 
rincian 1 orang guru (3\%) selalu, 3 orang guru (9\%) sering, dan 18 orang guru (51\%) kadang-kadang.

Hasil survei menunjukkan bahwa sebanyak 11 orang guru (31\%) tidak pernah mengukur luas daerah.
Berikutnya adalah sebanyak 24 orang guru $(69 \%)$ pernah menunjukkan lokasi tempat. dengan rincian 1 orang guru (3\%) selalu, 4 orang guru (12\%) sering, dan 19 orang guru (54\%) kadangkadang.

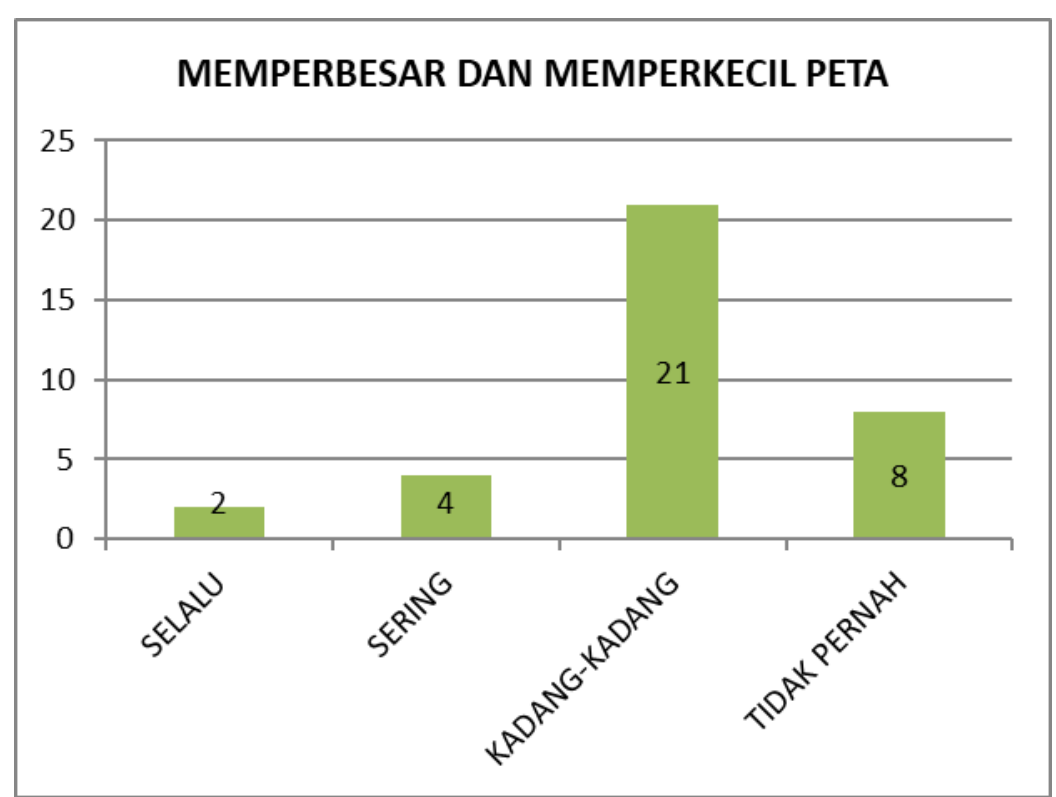

Gambar 14. Memperbesar dan Memperkecil Peta (Hasil Penelitian, 2021)

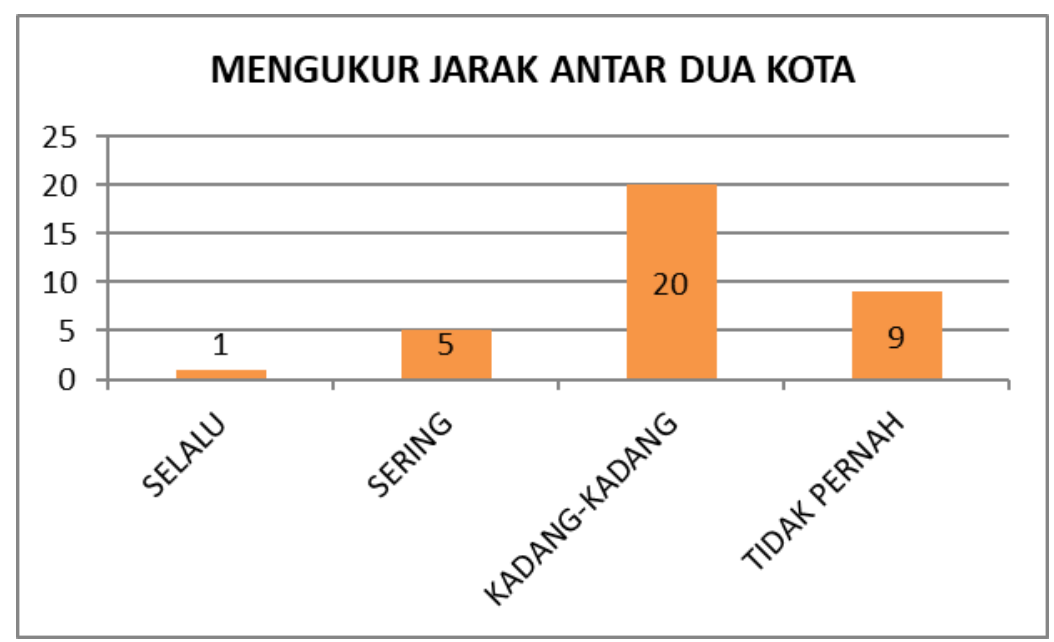

Gambar 15. Mengukur Jarak Antar Dua Kota (Hasil Penelitian, 2021)

Hasil survei menunjukkan bahwa sebanyak 8 orang guru $(23 \%)$ tidak pernah memperbesar dan memperkecil peta. Berikutnya adalah sebanyak 27 
orang guru $(77 \%)$ pernah menunjukkan lokasi tempat. Dengan rincian 2 orang guru $(6 \%)$ selalu, 4 orang guru $(11 \%)$ sering, dan 21 orang guru $(60 \%)$ kadang-kadang.

Hasil survei menunjukkan bahwa sebanyak 9 orang guru $(26 \%)$ tidak pernah mengukur jarak anrar dua kota. Berikutnya adalah sebanyak 26 orang guru $(74 \%)$ pernah menunjukkan lokasi tempat. Dengan rincian 1 orang guru (3\%) selalu, 5 orang guru (14\%) sering, dan 20 orang guru (57\%) kadangkadang.

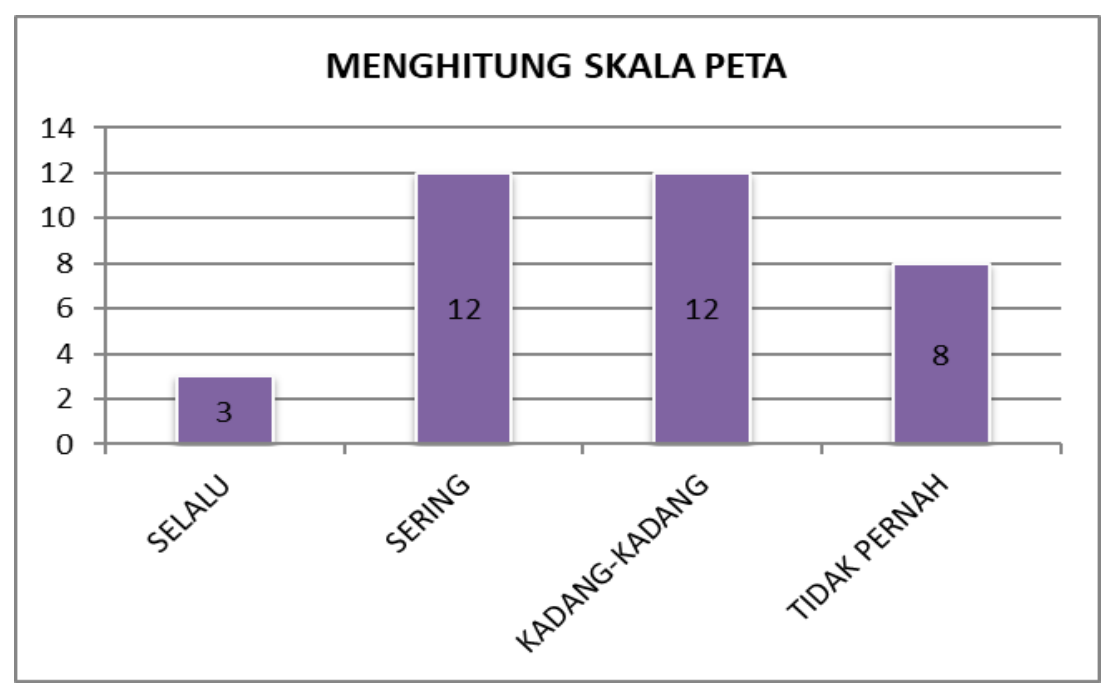

Gambar 16. Menghitung Skala Peta (Hasil Penelitian, 2021)

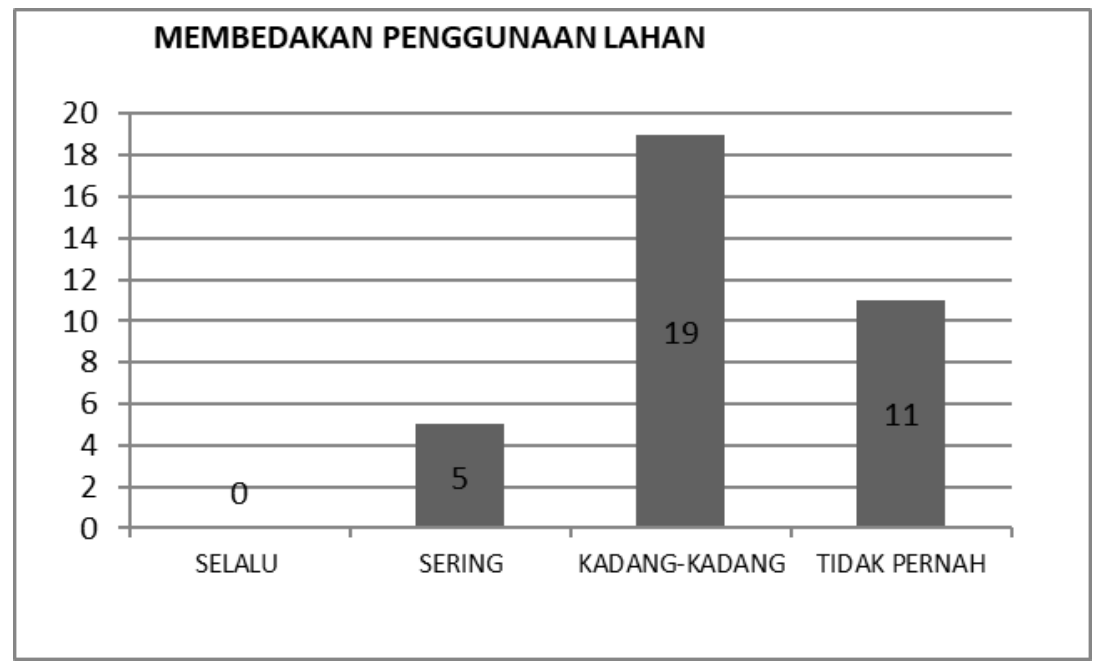

Gambar 17. Membedakan Penggunaan Lahan (Hasil Penelitian, 2021)

Hasil survei menunjukkan bahwa pernah menghitung skala peta. sebanyak 8 orang guru (23\%) tidak Berikutnya adalah sebanyak 27 orang 
guru (77\%) pernah menunjukkan lokasi tempat. Dengan rincian 3 orang guru (9\%) selalu, 12 orang guru (34\%) sering, dan 12 orang guru (34\%) kadangkadang.

Hasil survei menunjukkan bahwa sebanyak 11 orang guru (32\%) tidak pernah membedakan penggunaan lahan. Berikutnya adalah sebanyak 24 orang guru $(68 \%)$ pernah menunjukkan lokasi tempat. Dengan rincian 0 orang guru $(0 \%)$ selalu, 5 orang guru (14\%) sering, dan 19 orang guru (54\%) kadangkadang.

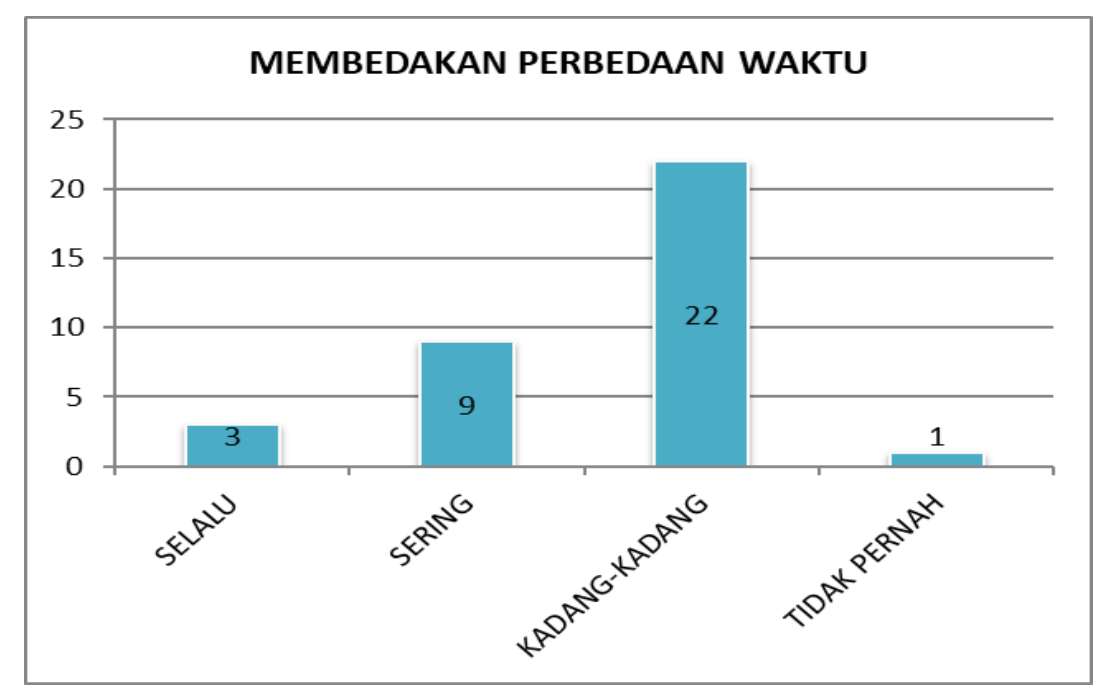

Gambar 18. Membedakan Perbedaan Waktu (Hasil Penelitian, 2021)

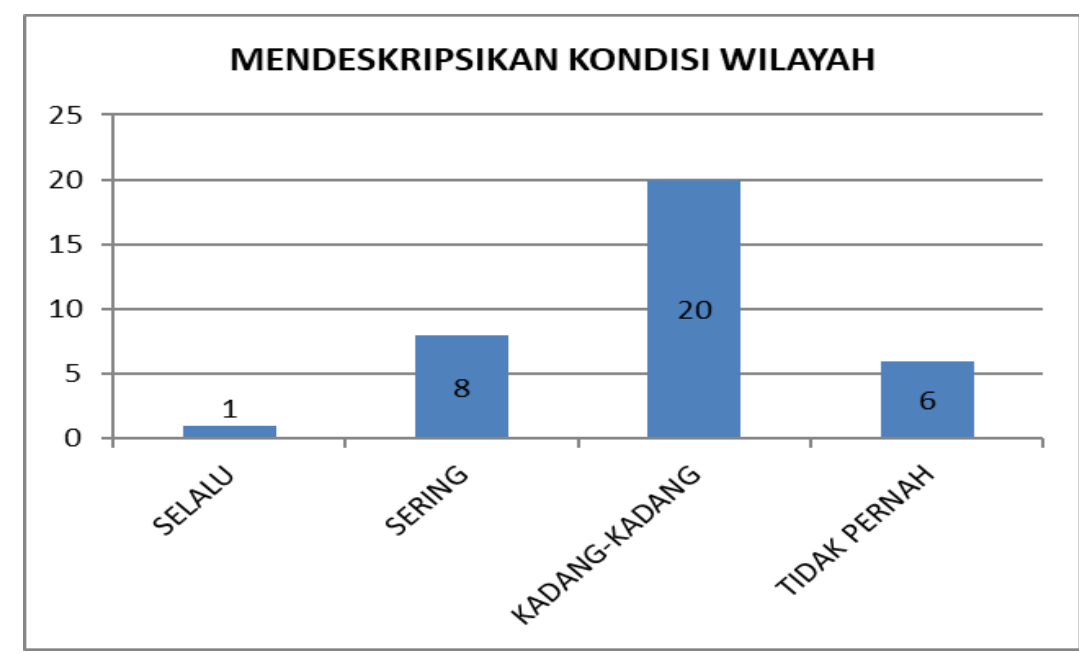

Gambar 19. Mendeskripsikan Kondisi Wilayah (Hasil Penelitian, 2021)

Hasil survei menunjukkan bahwa sebanyak 1 orang guru (3\%) tidak pernah membedakan perbedaan waktu. Berikutnya adalah sebanyak 34 orang 
guru (97\%) pernah menunjukkan lokasi tempat dengan rincian 3 orang guru (9\%) selalu, 9 orang guru (26\%) sering, dan 22 orang guru (62\%) kadang-kadang.

Hasil survei menunjukkan bahwa sebanyak 6 orang guru (17\%) tidak pernah mendeskripsikan kondisi wilayah. Berikutnya adalah sebanyak 29 orang guru $(83 \%)$ pernah menunjukkan lokasi tempat. Dengan rincian 1 orang guru $(3 \%)$ selalu, 8 orang guru $(23 \%)$ sering, dan 20 orang guru (57\%) kadangkadang.

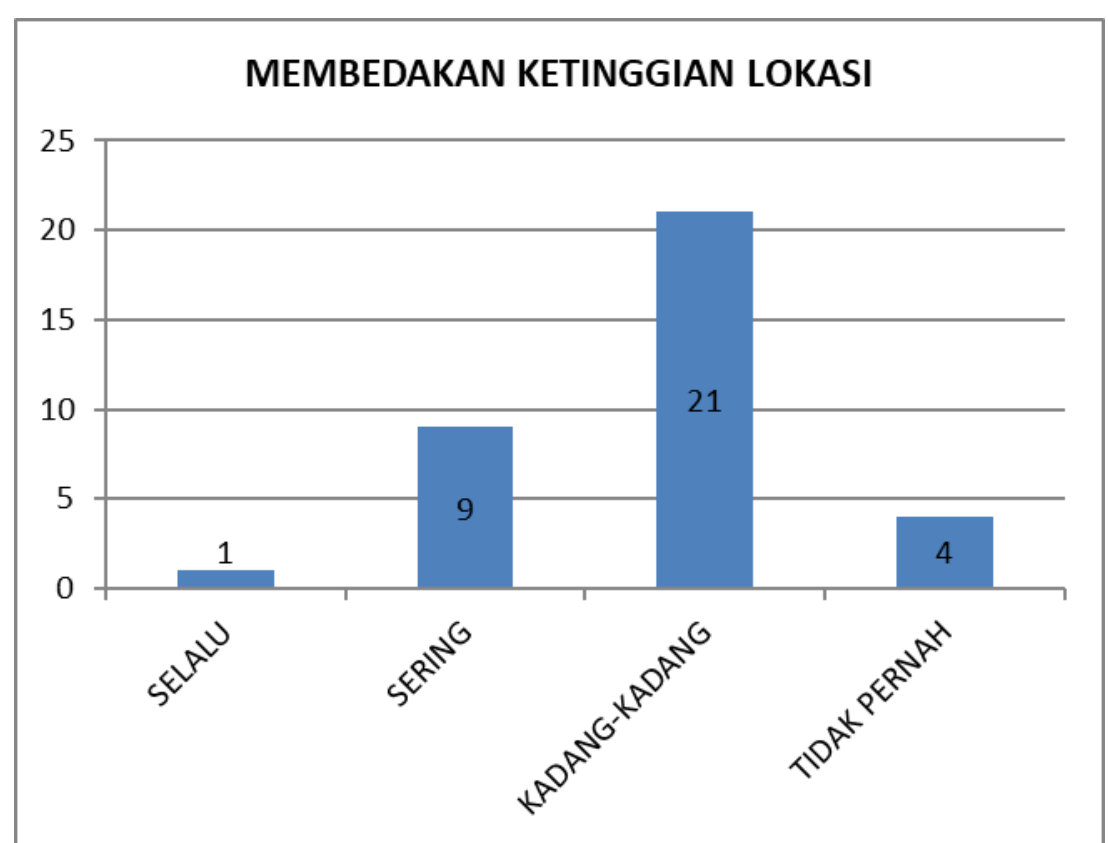

Gambar 20. Membedakan Ketinggian Lokasi (Hasil Penelitian, 2021)

Hasil survei menunjukkan bahwa sebanyak 4 orang guru (11\%) tidak pernah membedakan ketinggian lokasi. Berikutnya adalah sebanyak 31 orang guru $(89 \%)$ pernah menunjukkan lokasi tempat. Dengan rincian 1 orang guru
(3\%) selalu, 9 orang guru (26\%) sering, dan 21 orang guru (60\%) kadangkadang.

\section{Pemanfaatan Peta}

(1) Manfaat Peta Sebagai Media Pembelajaran 


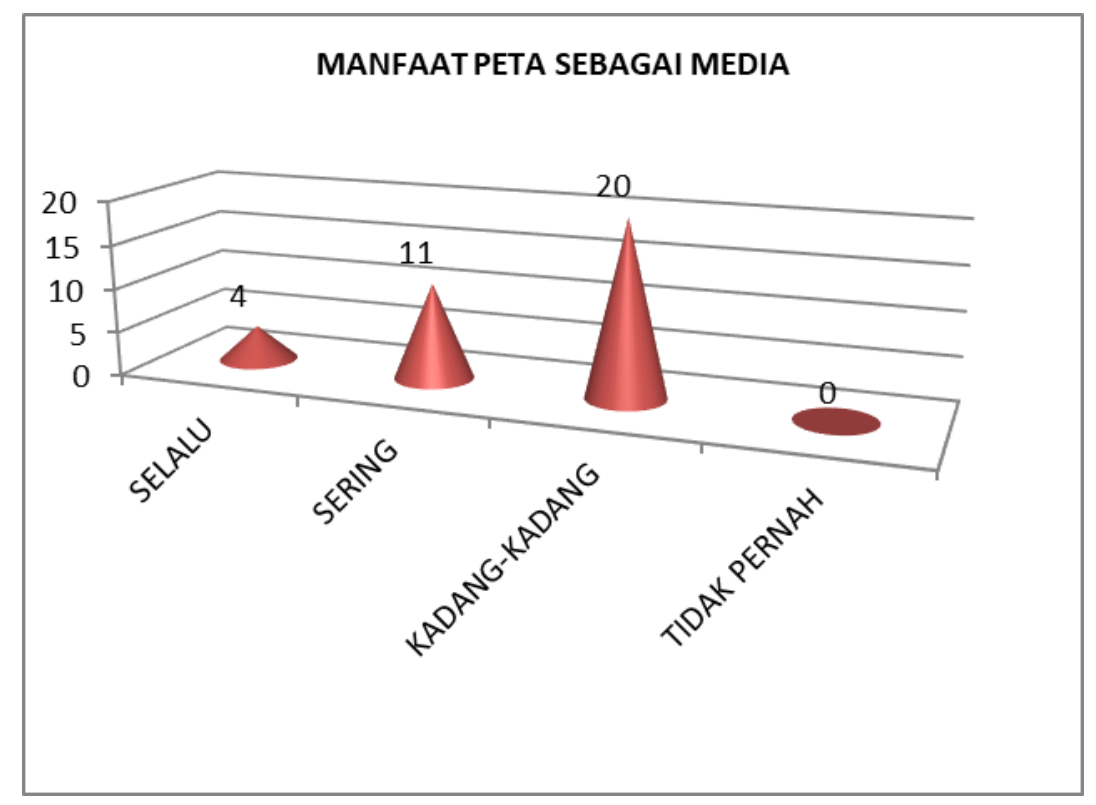

Gambar 21. Manfaat Peta Sebagai Media (Hasil Penelitian, 2021)

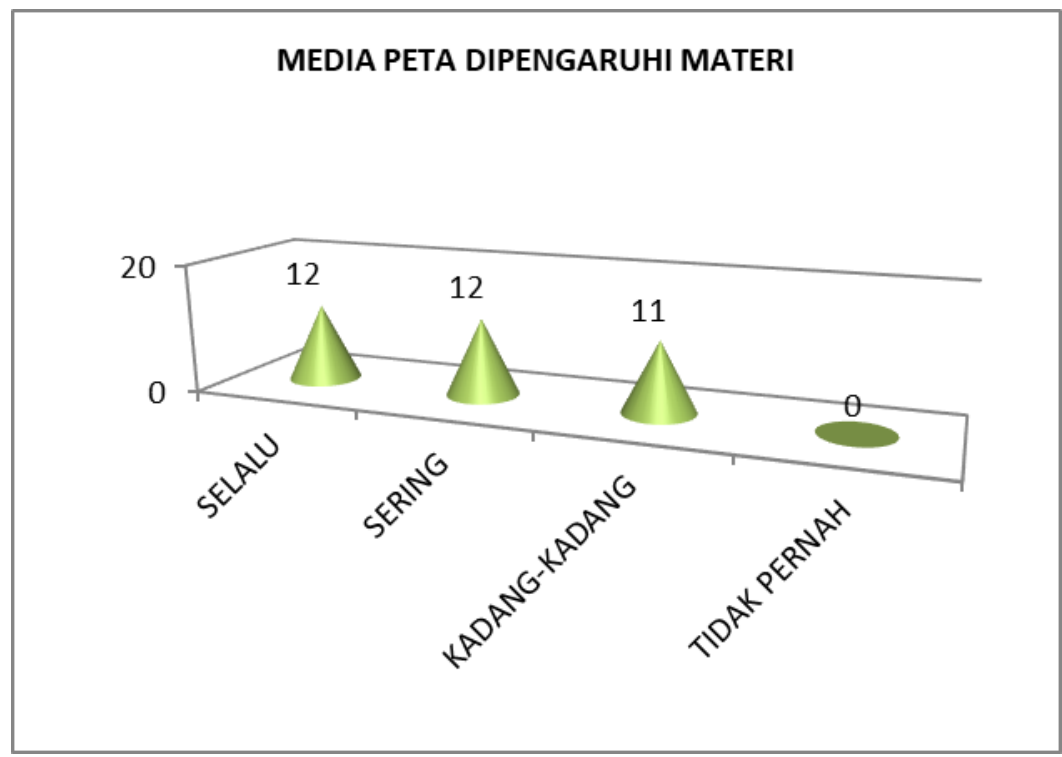

\section{Gambar 22. Media Peta Dipengaruhi Materi Pelajaran (Hasil Penelitian, 2021)}

Hasil survei menunjukkan bahwa sebanyak 35 orang guru (100\%) pernah memanfaatkan peta sebagai media. Dengan rincian 4 orang guru $(12 \%)$ selalu, 11 orang guru (31\%) sering, dan 20 orang guru (57\%) kadang-kadang.
Hasil survei menunjukkan bahwa sebanyak 35 orang guru (100\%) pernah memanfaatkan peta yang dipengaruhi oleh materi pelajaran. Dengan rincian 12 orang guru (34\%) selalu, 12 orang guru (34\%) sering, dan 11 orang guru (32\%) kadang-kadang. 


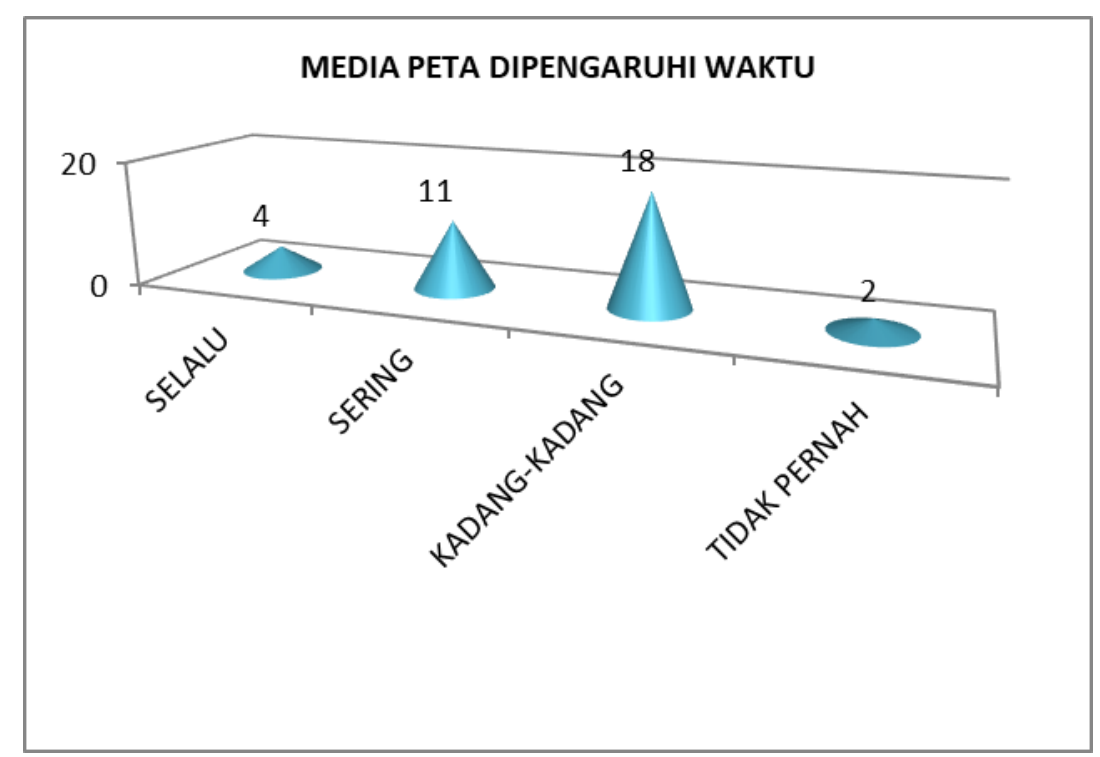

Gambar 23. Media Peta Dipengaruhi Waktu (Hasil Penelitian, 2021)

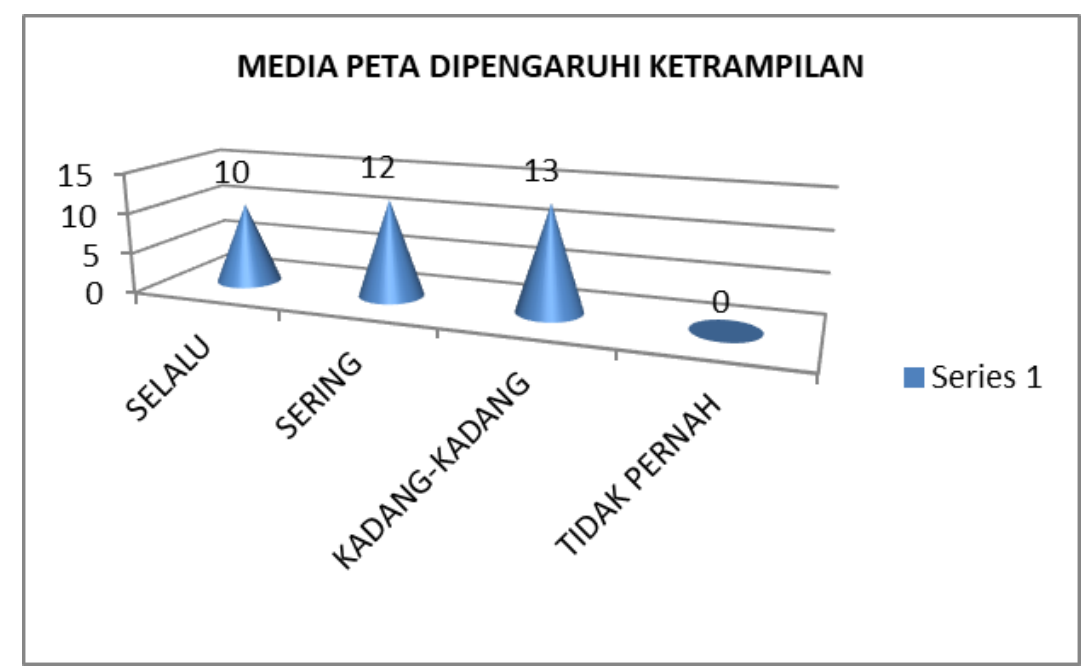

\section{Gambar 24. Media Peta Dipengaruhi Ketrampilan (Hasil Penelitian, 2021)}

Hasil survei menunjukkan bahwa sebanyak 33 orang guru (94\%) pernah memanfaatkan peta yang dipengaruhi oleh waktu, dengan rincian 4 orang guru (11\%) selalu, 11 orang guru (32\%) sering, dan 18 orang guru (51 \%) kadang-kadang dan sebanyak 2 orang guru $(6 \%)$ tidak pernah.
Hasil survei menunjukkan bahwa sebanyak 35 orang guru (100\%) pernah memanfaatkan peta yang dipengaruhi oleh materi pelajaran. Dengan rincian 12 orang guru (34\%) selalu, 12 orang guru (34\%) sering, dan 11 orang guru (32\%) kadang-kadang. 


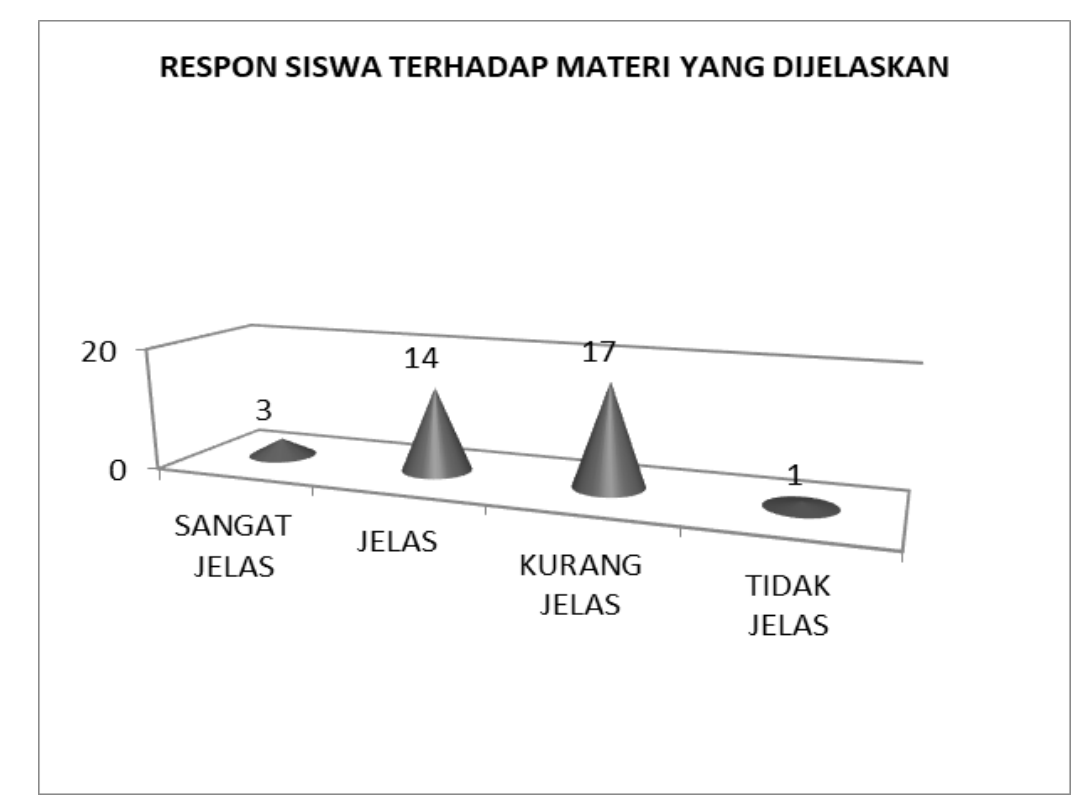

\section{Gambar 25. Respon Siswa Terhadap Materi Yang Dijelaskan}

(Hasil Penjelasan, 2021)

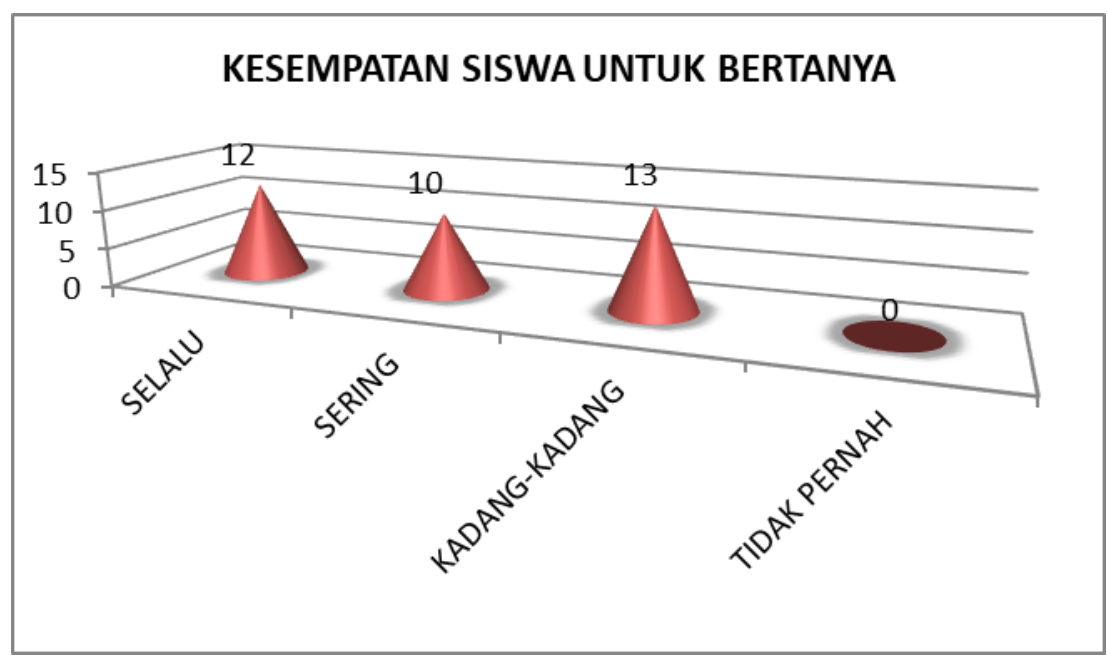

\section{Gambar 26. Kesempatan Siswa Untuk Bertanya (Hasil Penjelasan, 2021)}

Hasil survei menunjukkan bahwa sebanyak 35 orang guru (100\%) pernah memanfaatkan peta yang dipengaruhi oleh materi pelajaran. Dengan rincian 12 orang guru (34\%) selalu, 12 orang guru (34\%) sering, dan 11 orang guru $(32 \%)$ kadang-kadang.
Hasil survei menunjukkan bahwa sebanyak 35 orang guru (100\%) pernah memanfaatkan peta yang dipengaruhi oleh materi pelajaran. Dengan rincian 12 orang guru (34\%) selalu, 12 orang guru (34\%) sering, dan 11 orang guru (32\%) kadang-kadang. 
Kesempatan pembelajaran saat ini dengan keterlibatan siswa untuk mampu diarahkan untuk agar siswa kreatif, mencoba dalam penggunaan peta kritis, dan inovatif dalam kaitannya sebagai media.

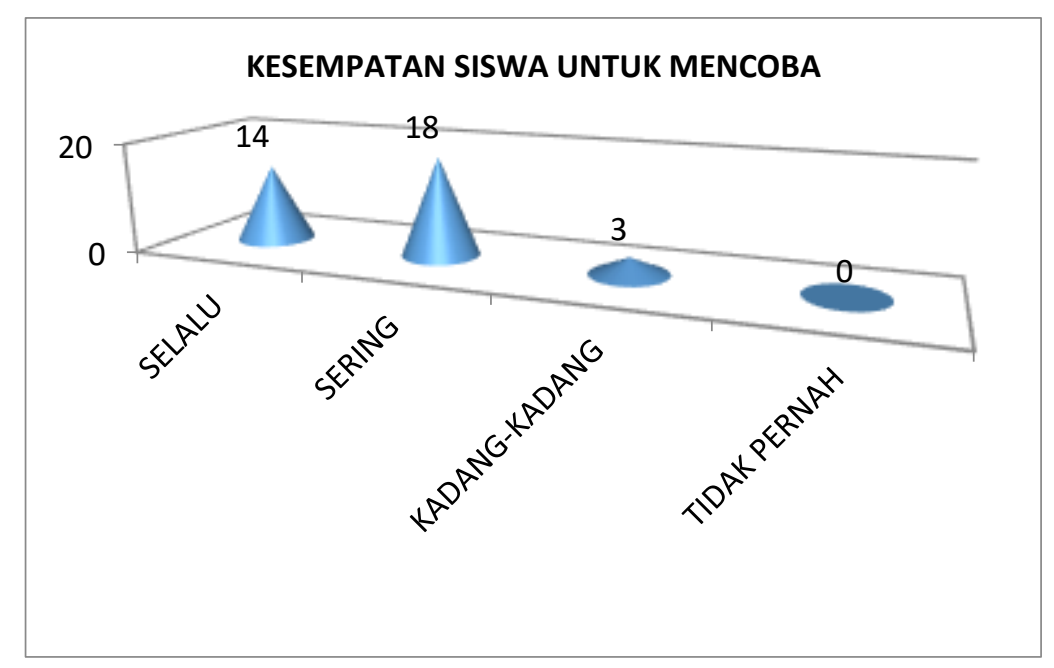

Gambar 27. Kesempatan Siswa Untuk Mencoba (Hasil Penelitian, 2021)

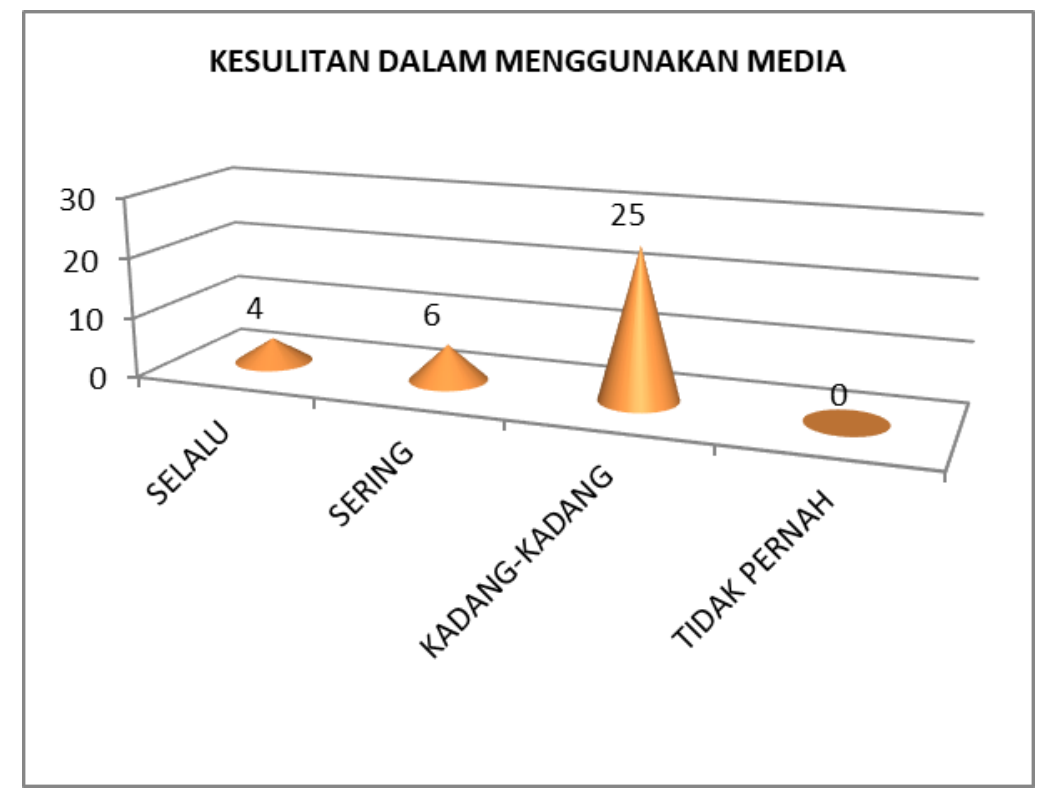

Gambar 28. Kesulitan Dalam Menggunakan Media Peta (Hasil Penelitian, 2021)

Hasil survei menunjukkan bahwa sebanyak 35 orang guru (100\%) pernah memberikan kesempatan kepada siswa untuk mencoba. Dengan rincian 14 orang guru $(40 \%)$ selalu, 18 orang guru
(51\%) sering, dan 3 orang guru (9\%) kadang-kadang.

Data pada gambar 28 tersebut dapat dijelaskan bahwa sejumlah 35 orang $(100 \%)$ pernah mengalami 
kesulitan dalam menggunakan media demikian, semua responden mengalami peta dengan rincian selalu 4 orang kesulitan dalam menggunakan peta (11\%), 6 orang $(17 \%)$ sering, dan 25 media pembelajaran.

orang (71\%) kadang-kadang. Dengan

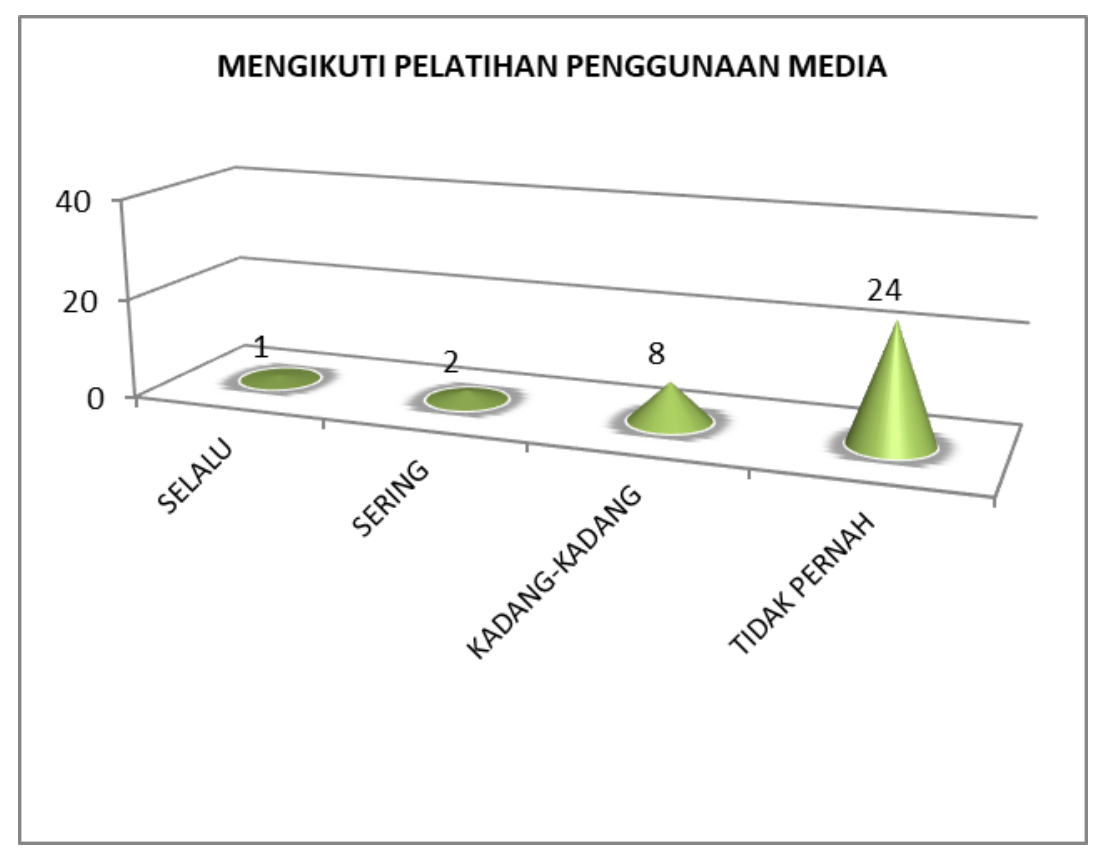

Gambar 29. Mengikuti Pelatihan Penggunaan Media (Hasil Penelitian, 2021)

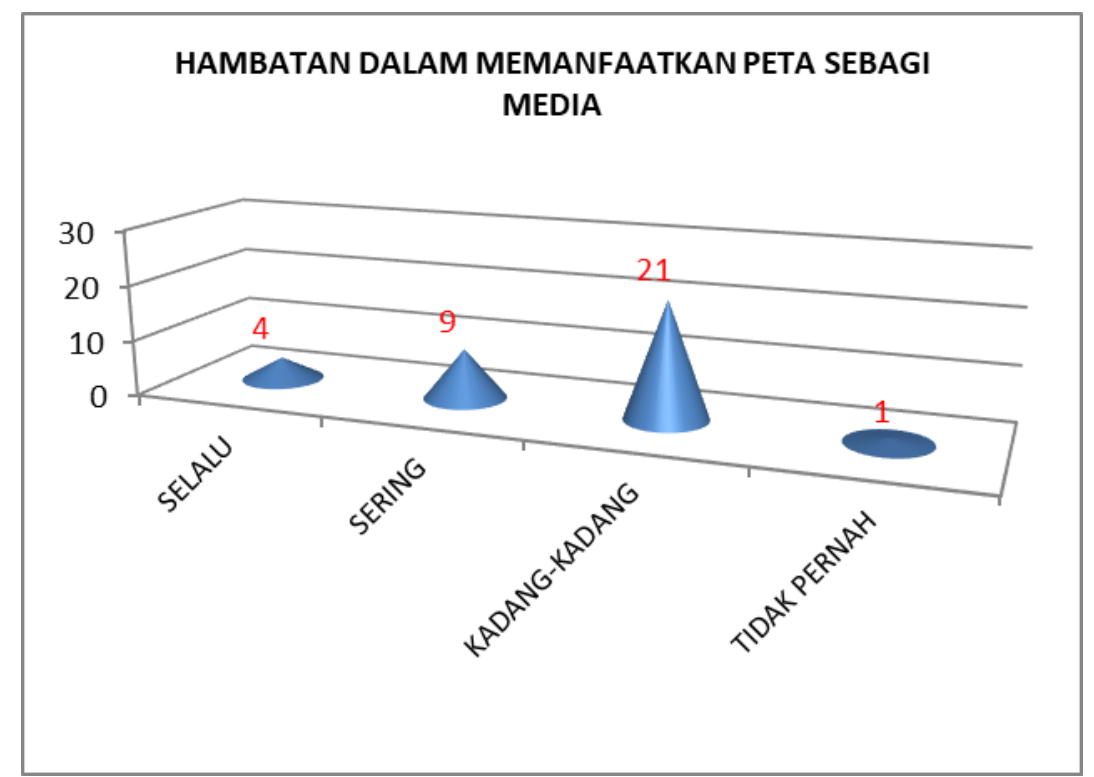

Gambar 30. Hambatan Dalam Memanfaatkan Peta Sebagai Media (Hasil Penelitian, 2021) 
Pelatihan merupakan salah satu bentuk pengayaan kompetensi yang memang harus untuk diikuti untuk meningkatkan keterampilan maupun pengetahuan khususnya tentang media pembelajaran berbasis peta. Data pada gambar 29 tersebut dapat dijelaskan bahwa sejumlah 1 orang (3\%) pernah mengikuti pelatihan dengan rincian selalu hanya satu orang, 2 orang $(6 \%)$ sering, dan 8 orang (23\%) kadangkadang. Sementara 24 orang (68\%) guru tidak pernah mengikuti pelatihan.

Berdasarkan data pada gambar 30 tersebut dapat dijelaskan bahwa para guru dalam melaksanakan proses pembelajaran melalui peta hanya satu orang guru $(2,85 \%)$ yang tidak pernah mengalami hambatan dalam memanfaatkan peta sebagai media dan sebagian besar guru sejumlah 34 orang $(97,15 \%)$ mengalami hambatan. Dengan rincian 4 orang guru (11\%) selalu mengalami hambatan, 9 orang ( 26 $\%)$ sering, dan 21 orang (60\%) kadangkadang mengalami hambatan.

Artinya bahwa masih ada sebagian besar guru mengalami hambatan dalam memanfaatkan peta sebagai media pembelajaran dimungkinkan karena keterbatasan kemampuan guru dalam bidang IT dan sarana media peta yang terbatas.

\section{Pembahasan}

Dari hasil survei dapat diketahui bahwa pada aspek yang berkaitan dengan ketrampilan guru dalam proses pembelajaran membuat peta kurang dari $80 \%$ nya pernah melaksanakan kegiatan tersebut kepada peserta didiknya, seperti menjelaskan cara membuat peta, menjelaskan atau menyebutkan alat dan bahan membuat peta maupun terkait dengan memberikan pekerjaan siswa untuk praktikum, dengan kata lain guru belum optimal pada proses pembuatan peta. Adanya perbedaan hasil belajar guru yang menggunakan peta dan tidak menggunakan peta (Mursiti, 2006).

Pada aspek yang berkaitan dengan membaca peta guru secara umum menyampaikan hal-hal penting pada peta yang disajikan sebagai media pembelajaran seperti menyebutkan judul peta, skala peta, arah/orientasi, simbol dan legenda, menunjukkan lintang dan bujur, menunjukkan tahun pembuatan peta serta menunjukkan lokasi tempat merupakan proses pembelajaran yang baik walaupun belum mencapai optimal. Adanya perbedaan hasil belajar materi membaca unsur-unsur peta lebih tinggi 
bagi yang menggunakan peta dan globe (Alwi, 2002). Kegiatan membaca peta bagi guru hampir selalu disampaikan dalam menjelaskan secara tematik dengan karakteristik dari wilayah yang disampaikan sebagai pokok bahasan. Beda dengan membuat peta, harus ada unsur lain yang terkait seperti alat dan bahan membuat peta maupun tugas yang diberikan oleh guru kepada siswanya. Jadi di sini ada keterlibatan secara langsung.

Sementara itu pada aspek menganalisis peta jarang melaksanakannya. Kenyataan ini mungkin disebabkan oleh keterbatasan alat perpetaan dan keterbatasan kepemilikan media yang tidak sebanding dengan jumlah siswa. Penggunaan media akan meningkatkan motivasi pembelajaran (Nurita, 2018) Analisis peta mempunyai tingkat kesulitan yang lebih tinggi dan dituntut dasar ilmu eksak atau matematika yang memadai baik bagi guru maupun siswanya.

Selanjutnya pada tahapan responden menginterpretasi peta, juga kadang-kadang melaksanakannya. Hal ini mungkin disebabkan karena keterbatasan media yang dimiliki terutama peta-peta tematik yang banyak menuntut untuk diinterpretasi. Tahapan menginterpretasi peta ini dianggap paling tinggi dan menuntut banyak keterampilan serta pemahaman pengetahuan ilmu-ilmu sosial maupun ilmu-ilmu alam. Sehingga bagi guru dan siswa jarang meresponnya dengan baik. Sedangkan permasalahan atau kesulitan dalam penggunaan peta itu hanya faktor internal dan eksternal guru saja.

Berdasarkan data tersebut menunjukkan bahwa sebenarnya terdapat keterkaitan antara kepemilikan media dan alat peraga dengan tingkatan penggunaan peta pada pengajaran geografi (IPS) di Sekolah Dasar. Keterkaitan ini diperjelas dengan pernyataan responden dalam hal permasalahan atau kesulitan yang dihadapi guru dalam penggunaan media di kelas. Sedangkan keterbatasan waktu atau kurangnya pelatihan diperlukan perhatian yang lebih khusus untuk penanganannya. Pendidikan dan latihan akan mempengaruhi keprofesionalisme guru dalam mengajar (Nurbaiti, 2011)

Pada tahapan pemanfaatan media pembelajaran IPS oleh guru, dari mulai menyiapkan atau menyediakan, pemakaian media, perencanaan media yang dipakai, serta faktor-faktor lain yang mempengaruhi penggunaan media tersebut menunjukkan hasil yang belum 
optimal. Banyak siswa yang belum memahami dalam peta, sehingga tidak aktif (Faisol, 2010).

\section{PENUTUP}

Berdasarkan pembahasan maka dapat disimpulkan hal-hal sebagai berikut:

1. Ada keterkaitan antara kepemilikan media pengajaran tema geografi terutama peta, atlas, dan globe serta kepemilikan alat perpetaan dengan kemampuan penggunaan peta dalam proses pembelajaran IPS pada tema kegeografian baik bagi guru yang bersangkutan maupun siswa khususnya.

2. Secara umum responden belum sepenuhnya melaksanakan kemampuan penggunaan peta baik dalam membaca peta, menganalisis peta, maupun menginterpretasi peta.

3. Faktor penyebab belum optimalnya kemampuan guru dalam penggunaan peta adalah adanya keterbatasan waktu dalam proses pembelajaran di kelas, keterbatasan kepemilikan media pembelajaran, dan belum adanya pelatihan tentang penggunaan peta dalam proses pembelajaran geografi bagi guru-guru.

\section{DAFTAR PUSTAKA}

Alwi. (2002). Penggunaan peta dan globe untuk meningkatkan prestasi belajar IPS di sekolah dasar. Jurnal Ilmu Pendidikan, 9(1).

Bintarto. (1988). Penuntun Geografi Sosial. Yogyakarta : UB Spring.

Dirgayusa, N.M., Dantes, N., \& Natajaya, I.N. (2015). Pengaruh penggunaan media peta taktual dalam pembelajaran terhadap motivasi belajar dan prestasi belajar IPS pada siswa SMALB di SLB A Negeri Denpasar. eJournal Program Pascasarjana Universitas Pendidikan Ganesha Program Studi Penelitian dan Evaluasi Pendidikan, 5(1).

Fathulloh Huda, F. \& Suprayitno. (2014). Penggunaan media peta untuk meningkatkan hasil belajar siswa pada mata pelajaran ilmu pendidikan sosial sekolah dasar. JPGSD, 2(3).

Faisol, M. (2010). Penggunaan media peta untuk meningkatkan aktivitas dan hasil belajar siswa pada lokasi, arah dan temapat dalam pelajaran IPS Kelas IV di SDN Sukoreno 01 Kec. Umbulsari. Program Studi Pendidikan Guru Sekolah Dasar Fakultas Keguruan 
Ilmu Pendidikan Universitas Jember.

Mursiti. (2006). Pengaruh penggunaan media peta terhadap hail belajar peta pada siswa mata pelajaran IPS Sejarah di SD Sampangan 03 Semarang. Pendidikan Sejarah, Fakultas Ilmu Sosial, Universitas Negeri Semarang.

Nurbaiti. (2011). Pengaruh pendidikan pelatihan dan pengalaman mengajar terhadap profesionalisme guru sekolah dasar di daerah binaan IV Kecamatan Comal Kabupaten
Pemalang. Prodi Pendidikan Guru Sekolah Dasar Universitas Negeri Semarang.

Nurita. (2018). Pengembangan media pembelajaran untuk meningkatkan hasil belajar. Myskat, 3(1).

Sumaatmadja, N. (1980). Metodologi pengajaran IPS. Bandung : Penerbit Alumni.

Suseno, M.A., Sugiyono, Uliyanti, E. (2014). Penggunaan media peta untuk meningkatkan hasil belajar siswa pada pembelajaran IPS di kelas V. Jurnal Pendidikan dan Pembelajaran Khatulistiwa, 3(7). 